\title{
Cyperaceae in Mexico: Diversity and distribution
}

\author{
M. Socorro González-Elizondo ${ }^{1 *}$, Anton A. Reznicek², and Jorge A. \\ TENA-FLORES ${ }^{1}$
}

Botanical Sciences 96 (2): 305-331, 2018

DOI: 10.17129/botsci.1870

Received:

October 2nd, 2017

Accepted:

November 10th, 2017

Associated Editor:

Guillermo Ibarra-Manríquez
${ }^{1}$ CIIDIR Unidad Durango, Instituto Politécnico Nacional, Durango, Mexico

${ }^{2}$ University of Michigan

Herbarium, Ann Arbor, MI,

USA.

*Corresponding author: herbario_ciidir@yahoo.com. $\mathrm{mx}$

This is an open access article distributed under the terms of the Creative Commons Attribution License CC $\mathrm{BY}-\mathrm{NC}(4.0)$ international.

\section{Abstract}

Background: Cyperaceae, with about 5,500 species and 90 genera worldwide, are the third largest family among Monocots. A unique combination of morphological and karyotypical features, among which stand holokinetic chromosomes, favors a rapid evolution and diversification and a high level of endemism in some groups. Preliminary checklists of Mexican sedges have been published but an updating of the taxonomy and nomenclature of the group for the country is required.

Questions: How many and which species and genera of Cyperaceae are in Mexico?, what patterns of geographic distribution display those species?, which are the main gaps in the systematic knowledge in the family?

Study site and years of study: Mexico, 1990 to 2016.

Methods: A database of Mexican Cyperaceae was generated with basis in literature review, study of herbarium specimens (11 herbaria in Mexico and the United States) and field work, the last mainly focused on Carex. Diversity and endemism level were calculated. Besides, we analyzed in different space scales their distributional range.

Results: Our dataset includes 460 species and 20 infraspecific taxa in 21 genera that belong to 10 of the 17 tribes of the family. Subfamily Cyperoideae includes almost $100 \%$ of the Mexican sedges, as only one representative of subfamily Mapanioideae is known for the country. At the generic level, a drastic reduction in number (21) in comparison to previous inventories (27) results of recent phylogenetic and taxonomic rearrangements. The most diverse genera are Carex (138 taxa) and Cyperus (125), followed by Rhynchospora (65) and Eleocharis (57). Sedges in Mexico are found from sea level to above 4,300 m, in all types of vegetation. The highest diversity was found for Chiapas (237 taxa, $52 \%$ of the total) and Veracruz (206 taxa, 45 \%), followed by Oaxaca and Jalisco. Two genera (Cypringlea and Karinia) and 111 species or infraspecific taxa are endemic to Mexico (24\%), 43 of them micro-endemic (only known from one state in the country). Endemism increases to $57 \%$ when the biogeographic extension known as Megamexico is included. Forty six names are excluded from the Mexican flora.

Conclusions: Regardless of the addition of taxa and refining of the databases, the checklist presented here is still preliminary. Collection deficiencies and insufficient taxonomic revision for Mexican sedges are reflected in gaps in their knowledge. There are at least 45 undescribed species; including them the richness of Mexican sedges would exceed 500 species. Many complexes of species are in need of taxonomic revision, mainly in Carex but also in Bulbostylis, Cyperus, Eleocharis, Rhynchospora and Scleria. To advance in the inventory and better understanding of the diversity of Mexican Cyperaceae, we propose some research topics to be addressed in the short term.

Key words: distribution, endemism, checklist, sedges, taxonomy.

\section{Resumen}

Antecedentes: La familia Cyperaceae es la tercera más grande entre las Monocotiledóneas, con unas 5,500 especies y 90 géneros. Presenta una combinación única de rasgos morfológicos y cariotípicos entre los que destacan los cromosomas holocinéticos (con centrómero no definido), lo cual favorece una rápida evolución cromosómica, una gran diversificación, altos ritmos de especiación y, en algunos grupos, altos grados de endemismo. Aunque se han publicado listas de las ciperáceas mexicanas, se requiere una actualización del conocimiento taxonómico y nomenclatural del grupo para el país.

Pregunta: ¿Cuántas y cuáles especies y géneros de Cyperaceae hay en México?, ¿Qué patrones de distribución geográfica presentan las especies?, ¿cuáles son las principales deficiencias en el conocimiento taxonómico de la familia? 
Sitio y años de estudio: México, de 1990 a 2016.

Métodos: Se generó una base de datos de las ciperáceas mexicanas a partir de revisión de literatura, estudio de especímenes en 11 herbarios de México y Estados Unidos y trabajo de campo, este último enfocado principalmente a Carex. Con base en esta información se cuantificó su riqueza y nivel de endemismo y se analizó a diferentes escalas espaciales su distribución geográfica.

Resultados: Se registran 460 especies y 20 taxa infraespecíficos de 21 géneros. Diez de las 17 tribus de la familia se encuentran representadas en México. La subfamilia Cyperoideae incluye casi el $100 \%$ de las especies mexicanas, ya que para el país se conoce solamente un representante de la subfamilia Mapanioideae. Se reportan menos géneros (21) en comparación a inventarios previos (27), derivado de arreglos taxonómicos con base en estudios filogenéticos recientes. Los géneros más diversos son Carex (138 taxa) y Cyperus (125), seguidos por Rhynchospora (65) y Eleocharis (57). Cyperaceae tiene distribución cosmopolita. En México, sus especies se encuentran desde el nivel del mar hasta a más de 4,300 m, en todos los tipos de vegetación. A nivel estatal, la mayor diversidad se encontró para Chiapas (237 taxa, $52 \%$ del total) y Veracruz (206 taxa, $45 \%$ ), seguidos por Oaxaca y Jalisco. Dos géneros (Cypringlea y Karinia) y 111 especies o taxa infraespecíficos son endémicos al país $(24 \%), 43$ de ellos microendémicos (solo se registran de un estado). El endemismo se incrementa a $57 \%$ cuando se calcula a nivel de las regiones de Megaméxico. Muchos nombres incluidos en registros previos corresponden a sinónimos y 46 nombres son excluidos de la flora del país.

Conclusiones: El listado florístico aquí presentado incluye varias adiciones a la flora ciperológica de México y actualizaciones nomenclaturales, a pesar de lo cual es todavía muy preliminar. La falta de suficientes colecciones y de revisiones taxonómicas de las ciperáceas mexicanas se refleja en huecos en su conocimiento. Hay por lo menos 45 especies por describir; si éstas se incluyen, la riqueza de ciperáceas mexicanas excedería las 500 especies. Se requieren revisiones taxonómicas en muchos complejos de especies en Carex, Bulbostylis, Cyperus, Eleocharis, Rhynchospora y Scleria. Se sugieren líneas de investigación futura para inventariar y caracterizar de manera más integral la diversidad de las ciperáceas mexicanas.

Palabras clave: ciperáceas, distribución, endemismo, listado, taxonomía.

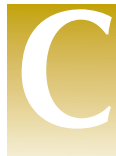

yperaceae (Poales) are a cosmopolitan, monophyletic family, the third largest among Monocots after Orchidaceae and Poaceae and the seventh among angiosperms, with about 5,500 species (Muasya et al. 2009a, b, Escudero \& Hipp 2013, Govaerts et al. 2015). Their origins are in the late Cretaceous (Escudero \& Hipp 2013) in what is now South America (Spalink et al. 2016). Known as sedges, they superficially resemble grasses or rushes, Juncaceae being its sister group (Jones et al. 2007).

Cyperaceae possess a unique combination of cytogenetical features: holokinetic chromosomes, possibility of inverted meiosis, and pseudomonad development (asymmetric tetrads). These characteristics favor karyotype differentiation for agmatoploidy (fission), symploidy (fusion), and polyploidy (Luceño \& Guerra 1997) as well as a broad variation in chromosome number ( $2 n=4$ to $2 n \geq 200$ ) (Roalson 2008). Chromosomes evolve more dynamically in sedges than in any other group of flowering plants and this, in turn, favors a rapid evolution and diversification and a high level of endemism in some groups (Hipp et al. 2006, 2009).

Sedges occur in a variety of habitats, being common in moist areas like wetlands, marshes, swamps, riverbanks, ponds and sandbank environments (Goetghebeur 1998), but they are well represented also in dry areas in many kinds of vegetation, including xerophytic scrub. Cyperaceae include several worldwide distributed genera. The largest genus is Carex L., one of the most species rich genera among angiosperms (Reznicek 1990a), with about 1,983 species, or nearly 2,000 species with the merger of satellite genera (The Global Carex Group 2015, 2016).

Most species have a great environmental value (e.g., as habitat and food for wild species and soil stabilizers) and many have ethnobotanical and economic importance (Bye 1979, DiegoPérez 1995, Simpson \& Inglis 2001, Ludlow-Wiechers \& Diego-Pérez 2002). Some are among the world's worst weeds, e.g., Cyperus rotundus L., C. esculentus L. and Fimbristylis miliacea (L.) Vahl (Bryson \& Carter 2008). Other species are used as food, as the tuberous nodules on the rhizomes of Cyperus esculentus and Eleocharis dulcis (Burm. f.) Trin. ex Hensch., or the rhizomes and tender young shoots of three species of Schoenoplectus (Rchb.) Palla, that were used by Native Americans (Rink \& Licher 2015). Among the ornamentals are Cyperus alternifolius 
L., C. involucratus Rottb. and C. papyrus L. Several species of Cyperus L., Eleocharis R. Br. and Schoenoplectus are used in phytoremediation (Rice et al. 1997, Wang et al. 2010).

Among the taxonomic reviews of Cyperaceae for Mexico or larger regions including the country are those for Abildgaardia, Bulbostylis \& Fimbristylis (Kral 1971), Carex (Hermann 1974), Cyperus (Tucker 1994), Eleocharis (Svenson 1929, 1932, 1934, 1937, 1939, 1957), Fuirena (Kral 1978), Lipocarpha (Goetghebeur \& Van den Borre 1989), Rhynchospora (Kükenthal 1949, 1950a, b, 1951, Thomas 1984, 1992, 1994), Scleria (Core 1936, 1965), as well as sections of Carex (Reznicek 1986, 1993a, Reznicek \& González-Elizondo 2001a, 2001b), Cyperus (Denton 1978), and Hypolytrum (Alves et al. 2015). Treatments of Cyperaceae for regional floras in Mexico include those in Flora Novo-Galiciana (McVaugh 1993, Reznicek 1993b, Tucker \& McVaugh 1993); Flora Mesoamericana (Adams 1994); Yucatan (Diego-Pérez 1995); Guerrero (Diego-Pérez 1997); Veracruz (Diego-Pérez 2008, 2012) and Valle de México (González-Elizondo 2001).

Additional references for the family in Mexico include descriptions of new taxa (e.g., Reznicek 1982, 1990b, González-Elizondo 1985, Tucker 1982, 1986, Cochrane 1981, Kral \& Thomas 1986, Reznicek \& González-Elizondo 1995, 1997, 1999, 2001a, González-Elizondo \& Reznicek 1997, 2005, Roalson 1999, Strong \& González-Elizondo 2000, Ramos-Álvarez \& Diego-Pérez 2002, González-Elizondo et al. 2005, 2007a, 2009, Reznicek et al. 2007, Rosen 2009, Saarela et al. 2010, Gómez-Sánchez et al. 2012, LeBlond et al. 2015); data on taxonomy or distribution (González-Elizondo \& Rzedowski 1983, 1984, Strong 1993, 1994, 2003, GonzálezElizondo \& Peterson 1997, Diego-Pérez et al. 2001, González-Elizondo \& Tena-Flores 2000, González-Elizondo et al. 2002, 2007b, Reznicek \& González-Elizondo 2008, Rosen et al. 2007, 2008a,b, Herbario CICY 2010 onwards), and uses or bioprospecting of sedges for pharmacology or phytoremediation (Flores-Tavizón et al. 2005, González-Elizondo et al. 2005, LópezMartínez et al. 2008, Pérez-López et al. 2009).

Preliminary checklists of Cyperaceae for Mexico include those of Espejo-Serna \& LópezFerrari (1997), Diego-Pérez \& González-Elizondo (2009) and Villaseñor (2016), but no conspectus of the family has been made for Mexico. An updating of the taxonomy and nomenclature of Mexican sedges is required to reflect recent taxonomic rearrangements in many genera as well as additions and exclusions of names for the Mexican flora. We present a checklist of the Cyperaceae currently known for Mexico with comments on diversity, endemism and distribution by state, and we discuss the main gaps in the knowledge of the family for the country.

\section{Materials and methods}

A database of Mexican Cyperaceae was generated with basis in literature review, study of herbarium specimens and field work. Most of the references are cited in the text, mainly at the Background, Methods and Discussion sections. Field work, mainly focused on Carex, has been done from 1990 to date in the whole country with the exception of the states of Guerrero, Quintana Roo, Tlaxcala and Yucatan. Herbaria reviewed from Mexico and elsewhere include CIIDIR, ENCB, GBH, HCIB, IBUG, IEB, INEGI, MICH, MEXU, QMEX, and SLPM (herbarium acronyms according to Thiers, continuously updated). Refining of the database involved nomenclatural updating, detection of synonyms, review of doubtful names and exclusion from the Mexican flora of names of taxa whose presence in the country has not been corroborated. The classification at the subfamily and tribe levels follows Muasya et al. (2009a, b) and the circumscription of genera follows Dorr (2014), Larridon et al. (2011, 2013, 2014), Bauters et al. (2014), and The Global Carex Group $(2015,2016)$. To verify the names of species and authors, the web sites Tropicos (www.tropicos.org) and The International Plant Names Index (www.ipni.org) were used.

From the dataset obtained, we calculated diversity, distribution by state and endemism level. Those taxa with distribution restricted to the country are considered as endemic, whereas microendemic are those known from only a state. Endemicity to a zone known as Megamexico (Rzedowski 1991) was also considered. It slightly extends the ecological conditions of the country, including three regions: MM1 (Mexico and zones of the Sonoran and Chihuahuan deserts and Tamaulipan scrub that lie in southern United States), MM2 (Mexico and the area of Central America northern of the Nicaraguan depression) and MM3 (MM1 and MM2). 
A comparison of the species richness among the Mexican states was made using absolute values, and also standardized values by applying Squeo et al. (1998) correction to soften the area effect: $\mathrm{S} / \mathrm{lnA}$ (species number/natural logaritm of the state area in $\mathrm{km}^{2}$ ).

\section{Results}

Cyperaceae are represented in Mexico by 460 species and 20 varieties or subspecies (480 taxa) which belong to 21 genera in 10 of the 17 family tribes. The checklist of taxa with state distribution and endemism level is presented in the Appendix 1. The two subfamilies currently recognized are in the country, with Cyperoideae including almost $100 \%$ of the species and Mapanioideae represented by only one species. The most diverse genera are Carex (138 species and varieties) and Cyperus (125), followed by Rhynchospora (65) and Eleocharis (57) (Table 1, Figure 1). The species previously treated under Uncina are at present recognized as Carex, whereas Kyllinga, Lipocarpha, Oxycaryum and Remirea are incuded in Cyperus. The main synonyms for those combinations are presented in Table 2.

At the state level, the highest richness was found in Chiapas (237 taxa, $52 \%$ of the total) and Veracruz (206, $45 \%$ ), followed by Oaxaca (171, 37 \%) and Jalisco (148, $32 \%$ ) (Figure 2, 3; Appendix 1). Two genera (Cypringlea and Karinia) and 111 species or infraspecific taxa are endemic to the country ( $24 \%), 78$ of them at a regional level, including 43 micro-endemics. Endemism increases to $57 \%$ when the biogeographic region known as Megamexico is included.

\section{Discussion}

The dataset of the Mexican sedge flora includes 460 species and 20 infraspecific taxa. Additionally, at least 45 undescribed species have been detected (not included in the checklist), which would increase to 525 the sedge taxa for the country.

Table 1. Cyperaceae in Mexico. Genera and number of species and subspecies/varieties by tribe and subfamily.

\begin{tabular}{|c|c|c|c|c|}
\hline Subfamilies & Tribes & Genera & Species & Subsp./Var. \\
\hline \multirow[t]{20}{*}{ Cyperoideae } & Abildgaardieae & Abildgaardia & 2 & \\
\hline & & Bulbostylis & 14 & \\
\hline & & Fimbristylis & 16 & \\
\hline & Cariceae & Carex & 137 & 1 \\
\hline & Cypereae & Cyperus & 113 & 12 \\
\hline & & Isolepis & 2 & \\
\hline & & Karinia & 1 & \\
\hline & Eleocharideae & Eleocharis & 55 & 2 \\
\hline & Fuireneae & Bolboschoenus & 2 & \\
\hline & & Fuirena & 7 & 2 \\
\hline & & Schoenoplectiella & 2 & \\
\hline & & Schoenoplectus & 5 & \\
\hline & Rhynchosporeae & Rhynchospora & 63 & 2 \\
\hline & Schoeneae & Cladium & 1 & 1 \\
\hline & & Schoenus & 1 & \\
\hline & Scirpeae & Amphiscirpus & 1 & \\
\hline & & Cypringlea & 3 & \\
\hline & & Scirpus & 4 & \\
\hline & Sclerieae & Calyptrocarya & 1 & \\
\hline & & Scleria & 29 & \\
\hline Mapanioideae & Hypolytreae & Hypolytrum & 1 & \\
\hline
\end{tabular}


Figure 1. Genera of Cyperaceae and number of species and infraspecific taxa in Mexico.

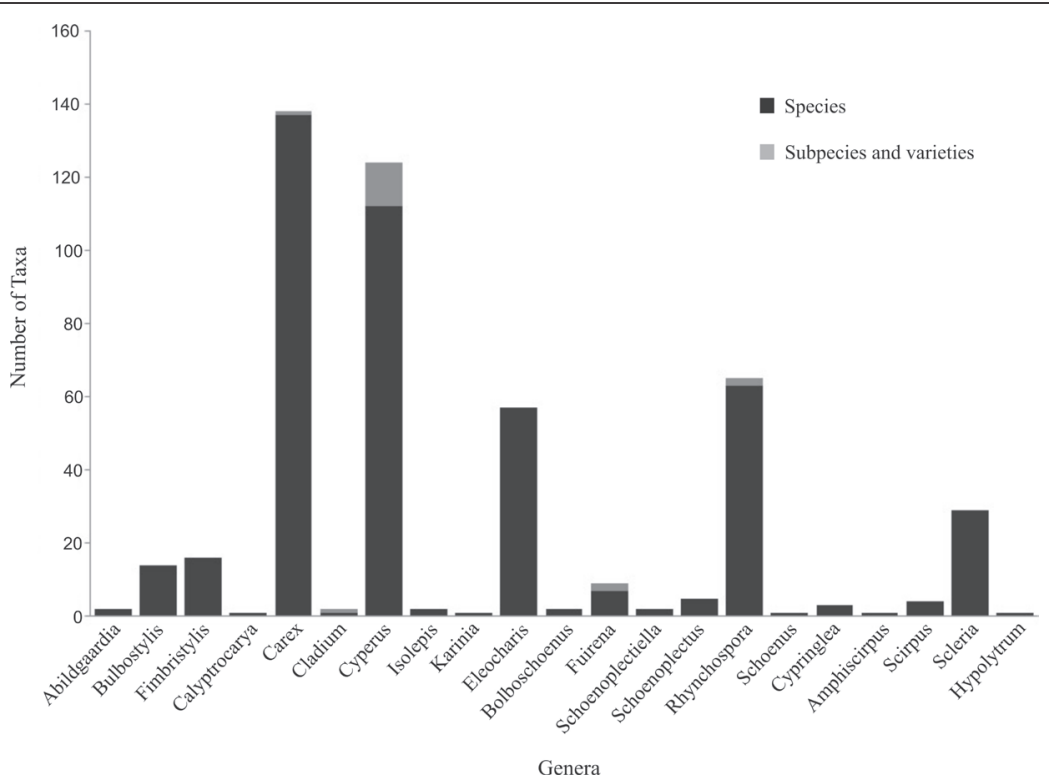

Suprageneric classification. The two subfamilies currently recognized (Cyperoideae and Mapanioideae) (Simpson et al. 2007, Muasya et al. 2009a) are in Mexico, although the predominantly tropical Mapanioideae is represented by only one species (Hypolytrum nicaraguense). As for the family tribes, 10 out of the 17 are in the country. The most diverse are Cariceae with 138 taxa and Cypereae with 128, whereas Hypolytreae is represented by one (Table 1). The Cariceae is a temperate group, mainly montane in Mexico, where represented by Carex (30\% of the taxa of this family). If compared with Madagascar, where the Cariceae are $11 \%$ of the Cyperaceae (Muasya et al. 2011) or with Brazil (4.4\%, Alves et al. 2009), the group is fairly well represented in Mexico although still not quite as in any boreal zone, e.g., North America, where it composes $57 \%$ of the sedge flora (Ball \& Reznicek 2002). On the other hand, the tribe Cypereae, mainly tropical, includes $28 \%$ of the sedge flora in Mexico, a high proportion when compared with North America (13\%) or even with Brazil (20\%), but low in relation with Madagascar, where the clade composes about half of the species in the family (Muasya et al. 2011).

Table 2. Main synonyms under Carex and Cyperus proposed or confirmed in recent studies: 1. Bauters et al. (2014), 2. Dorr (2014), 3. Larridon et al. (2011), 4. Larridon et al. (2013), 5. Larridon et al. (2014), 6. The Global Carex Group (2015).

\begin{tabular}{llc} 
Previous name & Accepted name & Source \\
\hline Kyllinga brevifolia Rottb. & Cyperus brevifolius (Rottb.) Endl. ex Hassk. & 5 \\
Kyllinga odorata Vahl & Cyperus sesquiflorus (Torr.) Mattf. \& Kük. & 5 \\
Kyllinga pumila Michx. & Cyperus hortensis (Salzm. ex Schltdl.) Dorr & 2,5 \\
Lipocarpha mexicana Liebm. & Cyperus lipomexicanus Goetgh. & 1 \\
Lipocarpha micrantha (Vahl) G. C. Tucker & Cyperus subsquarrosus (Muhl.) Bauters & 1 \\
Lipocarpha microcephala (R. Br.) Kunth & Cyperus leptocarpus (F. Muell.) Bauters & 1 \\
Lipocarpha salzmanniana Steud. & Cyperus salzmannianus (Steud.) Bauters & 1 \\
Oxycaryum cubense (Poeppig et Kunth) Palla & Cyperus blepharoleptos Steud. & 3 \\
Remirea maritima Aubl. & Cyperus pedunculatus (R. Br.) J. Kern & 4 \\
Uncinia hamata (Sw.) C.B. Clarke & Carex hamata Sw. & 6 \\
Unicinia koyamae Gómez-Laur. & Carex koyamae (Gómez-Laur.) J.R.Starr. & 6 \\
Uncinia phleoides (Cav.) Pers. & Carex phleoides Cav. & 6 \\
Uncinia tenuis Poepp. ex Kunth & Carex firmula (Kük.) J.R. Starr & 6
\end{tabular}


Figure 2. Number of species and infraspecific taxa of Cyperaceae by state.

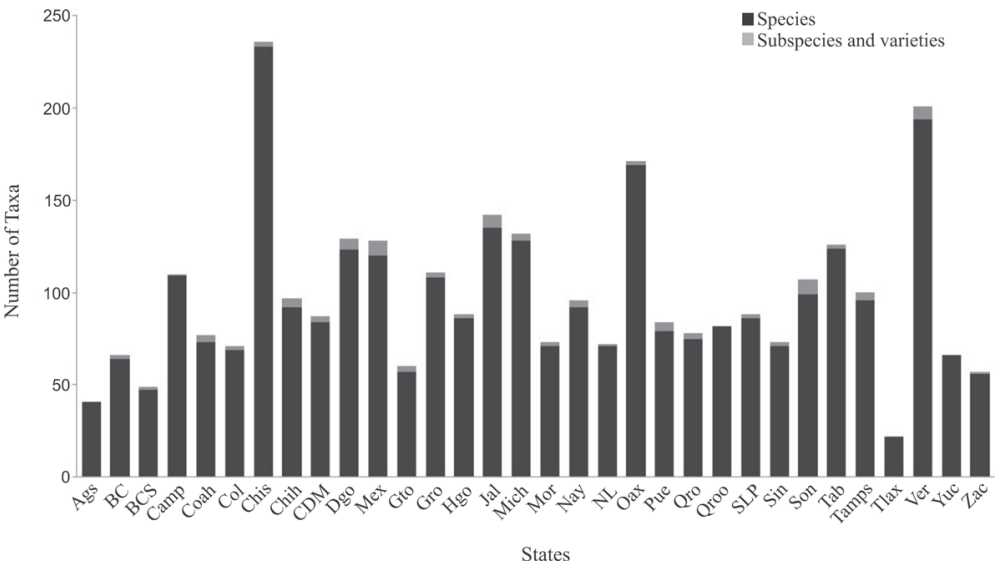

Current circumscription of genera. The number of genera recognized in the present contribution is 21 , which means a drastic reduction in comparison to previous inventories (27 genera recorded in Diego-Pérez \& González-Elizondo 2009 following Bruhl 1995; 26 genera in the checklist of Villaseñor 2016). This is a result of recent phylogenetic findings and taxonomic rearrangements (Larridon et al. 2011, 2013, 2014, Bauters et al. 2014, the Global Carex Group 2015, 2016). According to these references, Uncinia is included into Carex, whereas Kyllinga, Lipocarpha, Oxycarium and Remirea are now part of Cyperus (Table 2), besides Pycreus and Torulinum, previously subsumed. On the contrary, several genera are split from what was previously considered as Scirpus s.l. (Lye 2003, Strong 2003). The possition of Abildgaardia is debatable. It is placed in Fimbristylis by some authors (e.g., Govaerts et al. 2015), but it has a significantly different embryology and anatomy (Kral 2002).

The relationships of the two genera endemic to the country still require study. Cypringlea is closely related to Trichophorum Pers. (Léveillé-Bourret et al. 2014) whereas Karinia is related to Scirpoides Scheuchz. ex Seguier (Goetghebeur 1998) and has been recently combined under it as Scirpoides mexicanus (Reznicek \& McVaugh) Goetghebeur ex C.S. Reid \& J.R. Carter (Reid et al. 2017). Ball et al. (2002) pointed out that no consensus exists regarding the number of genera in Cyperaceae; that is still true in part, although new approaches to their study are rapidly increasing our understanding on the family.

Distribution and ecology. The state distribution data are preliminary. The highest richness was found in Chiapas and Veracruz, followed by Oaxaca (Figure 2, 3). Jalisco, Michoacán, Tabasco, Durango and the state of Mexico form the next richest group. However, it is possible that Durango and the state of Mexico are not actually among the richest states but they have just a more complete inventory of sedges. The data of species richness standardized with the logarithm of the state surface area (Figure 3) corroborates that the higher diversity is located in Chiapas and Veracruz and reveals that the lower is in Baja California Sur and Tlaxcala. As already said, this may be related to the thoroughness of the inventories. However, the richness by state is strikingly similar to the obtained by Dávila-Aranda et al. (in rev.) for Mexican Poaceae, with Chiapas, Veracruz, Oaxaca and Jalisco as the most diverse (in the same order than for Cyperaceae), and Baja California Sur and Tlaxcala among the three less diverse states, also as with sedges. Although Oaxaca is ranked as the richest state of vascular plants in Mexico (Villaseñor 2016), with regard to grasses and sedges it holds the third position, behind Chiapas and Veracruz. This may be a result of under-representation of grasses and sedges from Oaxaca in herbaria and floristic lists and a better knowledge about them for Chiapas and Veracruz, or it may be explained for ecological reasons (e.g., perhaps the open habitats preferred by sedges and grasses are less available in Oaxaca). These ideas are beyond of the scope of the present work and demand future research.

Sedges in Mexico are found from sea level to above 4,300 $\mathrm{m}$ and grow practically in all types of land vegetation, from tropical forests to xerophytic scrub. Besides, a little more than a fourth 


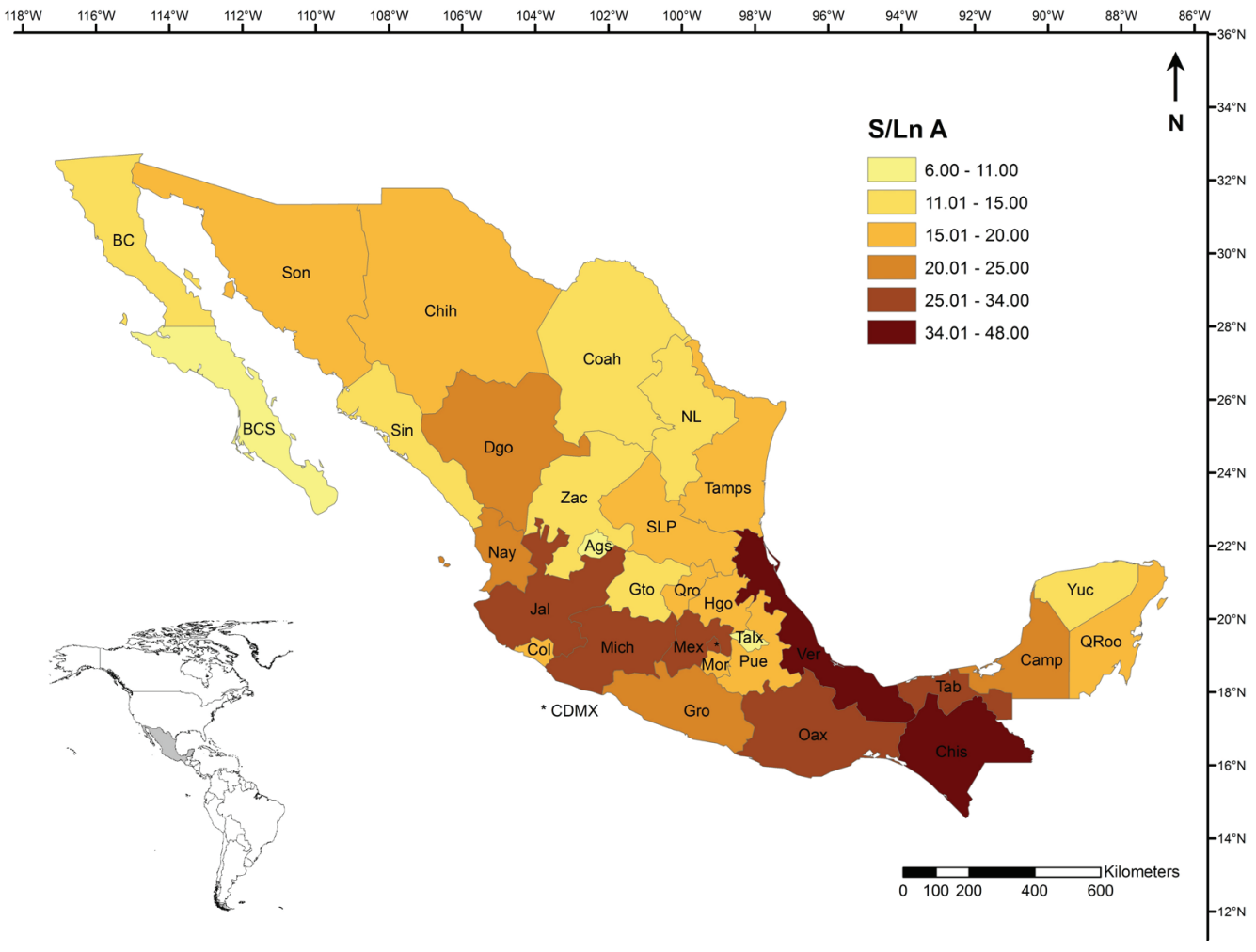

Figure 3. Cyperaceae species richness by state/surface area.

of the Mexican sedges are aquatic or subaquatic (Diego-Pérez \& González-Elizondo 2013), and many others, although not strictly aquatic, can be dominant in moist areas. However, other species can grow in dry areas in many types of vegetation. The wide variety of habitats that sedges can occupy explains in part the high diversity of this family in Mexico. Wetland loss and degradation, as well as overgrazing, are the main threats for many species of sedges (GonzálezElizondo \& Tena-Flores 2017).

Endemism. Two genera (Cypringlea and Karinia) and 109 species (and two infraspecific taxa) are endemic to the country (24\%). A total of 78 of those endemic species display a very narrow geographical range; in fact, 43 are known from only a state (micro-endemics) and almost a half of them belong to Carex. The proportion of sedges endemic to the country is almost the same as the proportion of endemic grasses (22.5\%) reported by Dávila-Aranda et al. (in rev.), mirroring the striking similitude of the distribution by state of sedges and grasses above discussed. Although, the proportion of sedges with distribution restricted to a single state is slightly higher than for grasses (38.7 and $32.6 \%$, respectively).

Most of the species with a very restricted distribution are montane, e.g., Carex austromexicana, C. durangensis, C. evadens, Eleocharis cryptica, E. svensoniana. Environmental heterogeneity and niche diversity in montane habitats foster restricted distribution and speciation in many species, as also occurs in groups like Asteraceae or Salvia (Lamiaceae) (Villaseñor et al. 1998, González-Zamora et al. 2007, Cornejo-Tenorio \& Ibarra-Manríquez 2011). JiménezMejías et al. (2011) found that small ecological changes are drivers for speciation in a group of European Carex. But the main driver for fast speciation in small populations in sedges appears to be the chromosomal plasticity and differentiation via fission, fusion, and polyploidy favoured by the diffuse kinetochore that is typical of sedges (Luceño \& Guerra 1996, Hipp et al. 2007).

Karinia mexicana, from the Mexican high plateau, is an example of regional endemism. Other species, although present in two or more states, have a restricted distribution, e.g., Carex eburnea in the Sierra Madre Oriental in Queretaro and San Luis Potosi; C. cochranei, C. her- 
mannii and C. interjecta in small areas of the Neovolcanic Belt; another example is Cypringlea coahuilensis, confined to limestone ridges in desert habitats in Coahuila and Nuevo Leon.

Sedge endemism in Mexico (24\%) is lower than in Brazil (30\%, Alves et al. 2009) and Madagascar (37\% from out 321 species, Muasya et al. 2011). On the other hand, there are no genera endemic to Brazil and only one is endemic to Madagascar. As a no insular country, Mexico shares a high proportion of its flora with neighbor countries. Nevertheless, endemism increases remarkably when the biogeographic region known as Megamexico (MM) (Rzedowski 1991 ) is considered (for a description see Methods section). As for Cyperaceae, $57 \%$ of the species are endemic to this region, which represents more than two-fold the ammount of sedges restricted to the political limits of the country. Some (e.g., Bulbostylis schaffneri, Carex bella, C. muriculata) are known from southwestern United States of America to northern or central Mexico (MM1); others, as Carex koyamae and E. yecorensis, are distributed from Mexico to Nicaragua (MM2); and a third group (e.g., Carex geophila, C. planostachys) distribute from southern United States of America to Central America (MM3). Another kind of regional endemics are those restricted to the Californian region, e.g., Carex globosa and C. triquetra, the first from moist places with conifers and the second from dry grasslands and scrub (Ball \& Reznicek 2002).

Excluded names for the Mexican flora. About 46 names are excluded from the Mexican flora. Among them are Bulbostylis juncoides (Vahl) Kük. ex Osten, and Carex brehmeri Boeckeler, whose distribution is restricted to South America, as well as Bolboschoenus fluviatilis (Torr.) Soják, Carex atrata L., Carex aurea Nutt., Carex densa (L.H. Bailey) L.H. Bailey, C. leporina L., and C. leptopoda Mack., which are known from North America or are Holarctic in distribution, but not known to reach Mexico.

Bulbostylis hirta (Thunb.) Svenson is a synonym of Fimbristylis squarrosa Vahl, a pantropical species whose presence in Mexico has not been confirmed; the Mexican and North American plants to which the name $B$. hirta has been misapplied shall be called Bulbostylis hispidula (Lye 2006). Lipocarpha humboldtiana Nees (= Cyperus sellowianus (Kunth) T. Koyama) is known from Honduras to South America, and Lipocarpha maculata (Michaux) Torrey (=Cyperus neotropicalis Alain), from eastern North America (Washington, D.C. to Florida). Lipocarpha mexicana (= Cyperus lipomexicanus Goetgh.) is considered as a synonym of L. maculata in recent catalogs but is recognized as an independent species in a revision of the group (Bauters et al. 2014).

Given that many previously cited names correspond to synonyms and 46 names are excluded here, the current number of recognized species (460) is lower than the 489 listed by CONABIO (Diego-Pérez \& González Elizondo 2009), although higher than the 416 species included in the checklist of Villaseñor (2016).

Some gaps in the knowledge of Mexican Cyperaceae. The cytology of a few species has been studied in Eleocharis (Tena-Flores et al. 2013) and Schoenoplectus (Tena-Flores et al. 2014) and Mexican species have been included in several molecular studies elsewhere. Nevertheless, many of the endemic species have not been cytogenetically or molecularly analyzed.

Collection deficiencies and insufficient taxonomic revision for Mexican sedges are reflected in gaps in their knowledge. It is very probable that species that are widely distributed may be in Mexico but have not yet been discovered in its territory. For example, Eleocharis confervoides (Poir.) Steud. is known from southeastern United States and eastern Central America and may be in coastal areas of Campeche and Yucatan. Some Cyperus are cited by Tucker (1994) as of probable presence in Mexico given that they are known from localities close to the Mexican border: Cyperus hayesii (C.B. Clarke) Standley from the Pacific coast from Guatemala to Colombia, and C. setigerus Torr. \& Hook. and C. strigosus L. from the United States of America reaching San Diego County and the Rio Grande plains, respectively.

Many complexes of species are in need of taxonomic revision. The main gaps in taxonomic knowledge are in Carex, as noted also elsewhere by Reznicek (1989), The Global Carex Group (2015), Jiménez-Mejías et al. 2016, among others. However, many problems remain to be solved also in Bulbostylis, Cyperus, Eleocharis, Rhynchospora and Scleria. Additional to the 
460 species recorded for the country, there are at least 45 undescribed species. With them, the net richness of Mexican sedges is of about 505 species plus 20 infraspecific taxa.

Therefore, regardless of the addition of taxa and refinement of the database of sedges for Mexico, the checklist presented here is still preliminary. There is still much basic work to be done before Mexican Cyperaceae are well understood.

\section{Acknowledgements}

Nelly Diego and Rosa Guaglianone $(\dagger)$ made valuable contributions to the knowledge of Mexican sedges. Gabriela López is collaborating to solve some taxonomic problems in Bulbostylis. Guillermo Ibarra Manríquez, Hilda Flores Olvera and Abisaí García Mendoza helped to improve a first version of the manuscript and two anonymous reviewers provided helpful suggestions. Curators and other staff of CIIDIR, ENCB, GBH, HCIB, IBUG, IEB, INEGI, MICH, MEXU, QMEX, and SLPM have facilitate access to specimens and the personnel at GH, MO, NY, P, PRC, and US have helped with loans or during short visits.

\section{Literature cited}

Adams CD. 1994. Cyperaceae Juss. In: Davidse G, Sousa Sánchez M, Chater AO, eds. Flora Mesoamericana 6. Mexico City Universidad Nacional Autónoma de México, 402-408. ISBN: 968-36-3310-2

Alves M, Araújo AC, Prata AP, Vitta F, Hefler S, Trevisan R, dos Santos Bragança Gil A, Martins S, Thomas W. 2009. Diversity of Cyperaceae in Brazil. Rodriguésia 60: 771-782. DOI: 10.1590/21757860200960405

Alves M, Lapa Wanderley MG, Thomas WW. 2015. Hypolytrum (Cyperaceae): taxonomic and nomenclatural notes, geographical distribution and conservation status of Neotropical species. Rodriguésia 66: 379-392. DOI: 10.1590/2175-7860201566208

Ball PW, Reznicek AA, Murray DF. 2002. Cyperaceae (descripción y clave para géneros). In: Flora of North America Editorial Committee, ed. Flora of North America North of Mexico Vol. 23. Magnoliophyta: Commelinidae (in part): Cyperaceae. New York: Oxford University Press, 3-8.

Ball PW, Reznicek AA. 2002. Carex, In: Flora of North America Editorial Committee eds. Flora of North America North of Mexico Vol. 23. Magnoliophyta: Commelinidae (in part): Cyperaceae. New York: Oxford University Press. <www.efloras.org/florataxon.aspx?flora_id=1\&taxon_id=105644>(accessed July, 2016).

Bauters K, Larridon I, Reynders M, Asselman P, Vrijdaghs A, Muasya AM, Simpson DA, Goetghebeur P. 2014. A new classification for Lipocarpha and Volkiella as infrageneric taxa of Cyperus s.1. (Cypereae, Cyperoideae, Cyperaceae): insights from species tree reconstruction supplemented with morphological and floral developmental data. Phytotaxa 166: 1-32. DOI: 10.11646/phytotaxa.166.1.1

Bruhl JJ. 1995. Sedge genera of the world: Relationships and a new classification of the Cyperaceae. Australian Systematic Botany 8: 125-305. DOI: 10.1071/SB9950125

Bryson CT, Carter R. 2008. The Significance of Cyperaceae as Weeds, In: Naczi RFC, Ford BA, eds. Sedges: Uses, Diversity, and Systematics of the Cyperaceae. St Louis, MO: Monographs in Systematic Botany from the Missouri Botanical Garden, 15-101. ISBN 978-1930723726

Bye R. 1979. Hallucinogenic plants of the Tarahumara. Journal of Etnopharmacology 1: 23-28.

Cochrane TS. 1981. Carex hermannii (Cyperaceae), a new species from Mexico, with comments on related species at high altitudes in Middle America. Brittonia 33: 225-232. DOI: 10.2307/2806329

Core EL. 1936. The American species of Scleria. Brittonia 2: 1-105.

Core EL. 1965. The genus Scleria in the Yucatan Peninsula. Wrightia 3: 141-160.

Cornejo-Tenorio G, Ibarra-Manríquez G. 2011. Diversidad y distribución del género Salvia (Lamiaceae) en Michoacán, México. Revista Mexicana de Biodiversidad 82: 1279-1296.

Dávila-Aranda P, Mejia-Saulés MT, Soriano Martínez AM, Herrera Arrieta Y. (in rev.) Conocimiento taxonómico de la familia Poaceae en México. Botanical Sciences.

Denton MF. 1978. A taxonomic treatment of the Luzulae group of Cyperus. Contributions from the University of Michigan Herbarium 11: 197-271.

Diego-Pérez N, González-Elizondo S. 2009. Ciperáceas (Monocotiledóneas), In: Sarukán J. coord. Catálogo taxonómico de especies de México, Capital Natural de México, Conocimiento Actual de la Biodiversidad. Mexico City: CONABIO, 56-91. ISBN: 978-607-7607-03-8

Diego-Pérez N. 1995. Familia Cyperaceae: Taxonomía, Florística y Etnobotánica. Etnoflora Yucatanense. Yucatán: Universidad Autónoma de Yucatán/Sostenibilidad Maya, 1-175. 
Diego-Pérez N. 1997. Cyperaceae. In: Diego-Pérez N, Fonseca RM, eds. Flora de Guerrero. Mexico City: Universidad Nacional Autónoma de México, 1-170.

Diego-Pérez N. 2008. La familia Cyperaceae del Estado de Veracruz. PhD. thesis, Universidad Nacional Autónoma de México.

Diego-Pérez N. 2012. Flora de Veracruz: Cyperaceae. Xalapa, Veracruz: Instituto de Ecología, 157: 1-487.

Diego-Pérez N, Ramos C, Martínez E. 2001. Un nuevo registro de Cyperus para México. Acta Botanica Mexicana 55: 17-20. DOI: 10.21829/abm55.2001.872

Diego-Pérez N, González-Elizondo MS. 2013. Cyperaceae. In: Lot A, Medina-Lemos R, Chiang F, eds. Plantas acuáticas mexicanas: una contribución a la Flora de México. Ciudad de Mexico: Universidad Nacional Autónoma de México, 85-164. ISBN: 978-607-02-4708-8

Dorr LJ. 2014. Flora of Guaramacal (Venezuela): Monocotyledons. Smithsonian Contributions to Botany 100: 1-289. DOI: $10.5479 /$ si.19382812.100

Escudero M, Hipp A. 2013. Shifts in diversification rates and clade ages explain species richness in higher-level sedge taxa (Cyperaceae). American Journal of Botany 100: 2403-2411. DOI: 10.3732/ ajb.1300162

Espejo-Serna A, López-Ferrari AL. 1997. Las Monocotiledóneas Mexicanas, una sinopsis florística, parte V. Cyperaceae. Ciudad de México: Consejo Nacional de la Flora de México-Universidad Autónoma Metropolitana Iztapalapa-Comisión Nacional para el Conocimiento y Uso de la Biodiversidad.

Flores-Tavizón E, Alarcón-Herrera MT, González-Elizondo S, Olguín EJ. 2003. Arsenic tolerating plants from mine sites and hot springs in the semi-arid region of Chihuahua, Mexico. Acta Biotechnologica 23: 113-119. DOI: 10.1002/abio.200390016

Goetghebeur P. 1998. Cyperaceae In: Kubitzki K., ed. The families and genera of vascular plants. Berlin: Springer, 141-190. DOI: 10.1007/978-3-662-03531-3_15 ISBN: 9783-642-08378-5

Goetghebeur P, Van den Borre A. 1989. Studies in Cyperaceae 8: A revision of Lipocarpha, including Hemicarpha and Rikliella. Agricultural University, 89: 1-87.

Gómez-Sánchez M, Cabrera-Luna A, González-Elizondo MS, Reznicek AA. 2012. Carex vizarronensis (Cyperaceae), a New Species of Carex section Schiedeanae from Central Mexico. Systematic Botany 37: 926-928. DOI: 10.1600/036364412X656527

González-Elizondo M, Tena-Flores JA. 2017. Las ciperáceas (Familia Cyperaceae). In: CONABIO. La Biodiversidad en Durango, Estudio de estado. Mexico City: CONABIO, 327-330. ISBN: 978-6078328-97-0

González Elizondo MS. 1985. Tres Nuevas especies Mexicanas de Cyperaceae. Phytologia 57: 381-385.

González-Elizondo MS. 2001. Cyperaceae. In: Calderón de Rzedowski G, Rzedowski J, eds. Flora Fanerogámica del Valle de México. Mexico City: Instituto de Ecología-CONABIO, 1114-1168. ISBN: 978-607-7607-36-6

González-Elizondo MS, Rzedowski J. 1983. Algunos aspectos ecológicos y fitogeográficos de las especies de Cyperaceae en el Valle de México. I. Afinidades ecológicas. Boletín de la Sociedad Botánica de México 45: 39-47. DOI: 10.17129/botsci.1297

González-Elizondo MS, Rzedowski J. 1984. Algunos aspectos ecológicos y fitogeográficos de las especies de Cyperaceae en el Valle de México. II. Análisis fitogeográfico. Boletín de la Sociedad Botánica de México 46: 29-35. DOI: 10.17129/botsci.1315

González-Elizondo MS, Peterson PM. 1997. A classification of and key to the supraspecific taxa in $\mathrm{El}$ eocharis (Cyperaceae). Taxon 46: 433-449. DOI: 10.2307/1224386

González-Elizondo S, Reznicek AA. 1997. Una nueva especie de Carex (Cyperaceae) de Querétaro. Acta Botanica Mexicana 40: 19-23. DOI: 10.21829/abm40.1997.779

González-Elizondo MS, Reznicek AA. 2005. Eleocharis ignota (Cyperaceae), a new species from western Mexico. Contributions from the University of Michigan Herbarium 24: 109-113.

González-Elizondo MS, Tena-Flores JA. 2000. Eleocharis (Cyperaceae) in the New World. In: Wilson KL, Morrison DA, eds. Monocots: systematics and evolution. Melbourne, Australia: CSIRO-Univ. New Gales. 637-643. ISBN: 9780643090149

González-Elizondo MS, González-Elizondo M, Smith GS. 2002. Eleocharis obtusetrigona (Cyperaceae) New to North and Central America. Acta Botanica Mexicana 60: 7-11. DOI: 10.21829/ abm60.2002.898

González-Elizondo MS, Tena-Flores J, Alarcón-Herrera T, Flores-Tavizón E, Barajas-Acosta N. 2005. An arsenic tolerant new species of Eleocharis (Cyperaceae) from Chihuahua, Mexico. Brittonia 57: 150154. DOI: 10.1663/0007-196X(2005)057[0150:AANSOE]2.0.CO;2

González-Elizondo MS, Rosen DJ, Carter R, Peterson PM. 2007a. Eleocharis reznicekii (Cyperaceae), a new species from the Mexican High Plateau. Acta Botanica Mexicana 81: 35-43. DOI: 10.21829/ abm81.2007.1050

González-Elizondo MS, González-Elizondo M, Tena-Flores JA, López-Enriquez IL, Reznicek AA, Di- 
ego-Pérez N. 2007b. Sinopsis de Scirpus s.1. (Cyperaceae) para México. Acta Botanica Mexicana 82: 15-41. DOI: 10.21829/abm82.2008.1055

González-Elizondo MS, González-Elizondo M, Tena-Flores JA, López-Enriquez IL, Enríquez-Enríquez ED. 2009. Eleocharis tenarum (Cyperaceae), a New Species from Durango and Zacatecas, Mexico. Novon 19: 164-167. DOI: $10.3417 / 2007048$

González Zamora A, Luna-Vega I, Villaseñor JL, Ruiz Jiménez CA. 2007. Distributional patterns and conservation of species of Asteraceae (asters etc.) endemic to eastern Mexico: A panbiogeographical approach. Systematics and Biodiversity 5: 135-144. DOI: 10.1017/S1477200006002192

Govaerts R, Jiménez-Mejías P, Koopman J, Simpson D, Goetghebeur P, Wilson K, Egorova T, Bruhl J. 2015. World Checklist of Cyperaceae. Facilitated by the Royal Botanic Gardens, Kew. <apps.kew. org/wcsp/qsearch.do> (accessed September 8, 2016).

Herbario CICY. 2010 en adelante. Flora de la Península de Yucatán. <www.cicy.mx/sitios/flora\%20digital/> (accessed March 11, 2017).

Hermann FJ. 1974. Manual of the Genus Carex in Mexico and Central America. Agr. Handbook 467. Washington: Forest Service, U.S.D.A., 1-219.

Hipp AL, Reznicek AA, Rothrock PE, Weber JA. 2006. Phylogeny and classification of Carex section Ovales (Cyperaceae). International Journal of Plant Sciences 167: 1029-1048. DOI: 10.1086/505538

Hipp AL, Rothrock PE, Reznicek AA, Berry PE. 2007. Changes in chromosome number associated with speciation in sedges: a phylogenetic study in Carex section Ovales (Cyperaceae) using AFLP data. Aliso 23: 193-203. DOI: 10.5642/aliso.20072301.14

Hipp AL, Rothrock PE, Roalson EH. 2009. The evolution of chromosome arrangements in Carex (Cyperaceae). Botanical Review 75: 96-109. DOI: 10.1007/s12229-008-9022-8

Jiménez-Mejías P, Escudero M, Guerra-Cárdenas S, Lye KA, Luceño M. 2011. Taxonomic delimitation and drivers of speciation in the Ibero-North African Carex sect. Phacocystis river-shore group (Cyperaceae). American Journal of Botany 98: 1855-1867. DOI: 10.3732/ajb.1100120

Jiménez-Mejías P, Fabbroni M, Donadío S, Rodríguez-Palacios GE, Hilpold A, Martín-Bravo S, Waterway MJ, Roalson EH. 2016. Taxonomic and distribution notes on Carex (Cyperaceae) from the Neotropics. Boletín de la Sociedad Argentina de Botánica 51: 727-739.

Jones E, Simpson DA, Hodkinson TR, Chase MW, Parnell MW. 2007. The Juncaceae-Cyperaceae Interface: A Combined Plastid Sequence Analysis. Aliso 23: 55-61. DOI: 10.5642/aliso.20072301.07

Kral R. 1971. A treatment of Abildgaardia, Bulbostylis and Fimbristylis (Cyperaceae) for North America. Sida 4: 57-227.

Kral R. 1978. A synopsis of Fuirena (Cyperaceae) for the Americas north of South America. Sida 7: 309 354.

Kral R. 2002. Abildgaardia. In: Flora of North America Editorial Committee, ed. Flora of North America North of Mexico: Magnoliophyta: Commelinidae (in part): Cyperaceae. New York: Oxford University Press, 1-608. ISBN: 978-0195152074

Kral R, Thomas WW. 1986. Two New Species of Rhynchospora (Cyperaceae) from Mexico. Brittonia 38: 210-215. DOI: 10.2307/2807338

Kükenthal G. 1949. Rhynchospora. Vorarbeiten zu einer Monographie der Rhynchosporoideae. Botanische Jahrbücher fur Systematik, Pflanzengeschichte und Pflanzengeographie 74: 375-509.

Kükenthal G. 1950a. Rhynchospora. Vorarbeiten zu einer Monographie der Rhynchosporoideae. Botanische Jahrbücher fur Systematik, Pflanzengeschichte und Pflanzengeographie 75: 90-126.

Kükenthal G. 1950b. Rhynchospora. Vorarbeiten zu einer Monographie der Rhynchosporoideae. Botanische Jahrbücher fur Systematik, Pflanzengeschichte und Pflanzengeographie 75: 127-195.

Kükenthal G. 1951. Rhynchospora. Vorarbeiten zu einer Monographie der Rhynchosporoideae. Botanische Jahrbücher fur Systematik, Pflanzengeschichte und Pflanzengeographie 75: 273-314.

Larridon I, Reynders M, Huygh W, Bauters K, Vrijdaghs A, Leroux O, Muasya AM, Simpson DA, Goetghebeur P. 2011. Taxonomic changes in C3 Cyperus (Cyperaceae) supported by molecular data, morphology, embryography, ontogeny and anatomy. Plant Ecology and Evolution 144: 327-356. DOI:10.5091/plecevo.2011.653.

Larridon I, Bauters K, Reynders M, Huygh W, Muasya AM, Simpson DA, Goetghebeur P. 2013. Towards a new classification of the giant paraphyletic genus Cyperus (Cyperaceae): phylogenetic relationships and generic delimitation in C4 Cyperus. Botanical Journal of the Linnean Society 172: 106-126. DOI: 10.1111/boj. 12020

Larridon I, Bauters K, Huygh W, Reynders M, Goetghebeur P. 2014. Taxonomic changes in C4 Cyperus (Cypereae, Cyperoideae, Cyperaceae): combining the sedge genera Ascolepis, Kyllinga and Pycreus into Cyperus s.1. Phytotaxa 166: 33-48. DOI: 10.11646/phytotaxa.166.1.2

LeBlond RJ, Tessel SM, Poindexter DB. 2015. Scleria bellii (Cyperaceae), a distinctive and uncommon nutsedge from the southern U.S., Cuba, and Mexico. Journal of the Botanical Research Institute of Texas 9: 31-41. 
Léveillé-Bourret B, Gilmour CN, Starr JR, Naczi RFC, Spalink D, Sytsma KJ. 2014. Searching for the sister to sedges (Carex): resolving relationships in the Cariceae-Dulichieae-Scirpeae clade (Cyperaceae). Botanical Journal of the Linnean Society 176: 1-21. DOI: 10.1111/boj.12193.

López-Martínez S, Gallegos-Martínez ME, Perez-Flores LJ, Gutiérrez-Rojas M. 2008. Contaminated soil phytoremediation by Cyperus laxus Lam. Cytochrome P450 EROD-Activity induced by hydrocarbons in roots. International Journal of Phytoremediation 10: 289-301. DOI: 10.1080/15226510802096069.

Luceño M, Guerra M. 1997. Numerical variation in species exhibiting holocentric chromosomes: a nomeclatural proposal. Caryologia 49: 301-309. DOI: 10.1080/00087114.1996.10797374

Ludlow-Wiechers B, Diego-Pérez N. 2002. Utilidad e importancia histórica y cultural de las Cyperaceae. Etnobiología 2: 90-102.

Lye KA. 2003. Schoenoplectiella Lye, gen. nov. (Cyperaceae). Lidia. 6: 20-29.

Lye KA. 2006. The typification and identity of Cyperus hirtus Thunb. (1803). Taxon 55: 1025-1026. DOI: $10.2307 / 25065701$

McVaugh R. 1993. Cyperaceae. In: Anderson W, ed. Flora Novo-Galiciana. Ann Arbor: The University of Michigan Herbarium, 270-344.

Muasya AM, Simpson DA, Verboom GA, Goetghebeur P, Naczi RFC, Chase MW, Smets E. 2009a. Phylogeny of Cyperaceae based on DNA sequence data: current progress and future prospects. Botanical Review 75: 2-21. DOI: 10.1007/s12229-008-9019-3

Muasya AM, Vrijdaghs A, Simpson DA, Chase MW, Goetghebeur P, Smets E. 2009b. What is a genus in Cypereae: Phylogeny, character homology assessment and generic circumscription in Cypereae. Botanical Review 75: 52-66. DOI: 10.1007/s12229-008-9018-4

Muasya AM, Larridon I, Reynders M, Huygh W, Goetghebeur P, Cable S, Simpson DA, Gehrke B. 2011. The Cyperaceae in Madagascar show increased species richness in upland forest and wetland habitats. Plant Ecology and Evolution 144: 357-362. DOI:10.5091/plecevo.2011.619

Pérez-López ME, González-Elizondo MS, López-González C, Martínez-Prado A, Cuevas-Rodríguez G. 2009. Aquatic macrophytes tolerance to domestic wastewater and their efficiency in artificial wetlands under greenhouse conditions. Hidrobiológica 19: 233-244.

Ramos-Álvarez CH, Diego-Pérez N. 2002. Una especie nueva de Fuirena (Cyperaceae) del estado de Campeche, México. Acta Botanica Mexicana 58: 51-55. DOI: 10.21829/abm58.2002.889

Reid C, Doyle VP, Carter JR, Vargas-Rodriguez Y, Urbatsch LE. 2017. Molecular systematics of targeted flat sedges (Cyperus, Cyperaceae) of the Americas. Plant Ecology and Evolution 150: 343-357. DOI: 10.5091/plecevo.2017.1262

Reznicek AA. 1982. Two new species of Carex (Cyperaceae) from Southern Mexico. Systematic Botany 7: 340-344. DOI: $10.2307 / 2418393$

Reznicek AA. 1986. The taxonomy of Carex Sect. Hymenochlaenae (Cyperaceae) in Mexico and Central America. Systematic Botany 11: 56-87. DOI: 10.2307/2418947

Reznicek AA. 1989. New England Carex (Cyperaceae): taxonomic problems and phytogeographical considerations. Rhodora 91: 144-152.

Reznicek AA. 1990a. Evolution in Sedges (Carex, Cyperaceae). Canadian Journal of Botany 68: 14091432. DOI: $10.1139 / \mathrm{b} 90-180$

Reznicek AA. 1990b. Four new species of Carex (Cyperaceae) from Mexico, with notes on the Mexican Carex flora. Contributions from the University of Michigan Herbarium 17: 279-293.

Reznicek AA. 1993a. Revision of Carex Section Ovales (Cyperaceae) in Mexico. Contributions from the University of Michigan Herbarium 19: 97-136.

Reznicek AA. 1993b. Carex. In: Anderson W, ed. Flora Novo-Galiciana. Ann Arbor: The University of Michigan Herbarium, 243-267.

Reznicek AA, González-Elizondo MS. 1995. The Carex lurida group in the Neotropics. Contributions from the University of Michigan Herbarium 20: 217-230.

Reznicek AA, González-Elizondo MS. 1997. Two New species of Carex (Cyperaceae) from Mexico. Contributions from the University of Michigan Herbarium 21: 291-297.

Reznicek AA, González-Elizondo MS. 1999. New species of Carex (Cyperaceae) from Chiapas, Mexico. Contributions from the University of Michigan Herbarium 22: 121-130.

Reznicek AA, González-Elizondo MS. 2001a. Additions to the Carex lurida group (Cyperaceae) in Mexico, including a new species from Chiapas. Contributions from the University of Michigan Herbarium 23: 333-337.

Reznicek AA, González-Elizondo MS. 2001b. Carex Section Porocystis in Mexico and Central America. Contributions from the University of Michigan Herbarium 23: 339-348.

Reznicek AA, González-Elizondo MS. 2008. Cypringlea (Cyperaceae) revisited, a new combination and status. Acta Botanica Mexicana 83: 1-11. DOI: 10.21829/abm83.2008.1057

Reznicek AA, Hipp A, González-Elizondo MS. 2007. Carex michoacana, a new species of Carex section 
Ovales (Cyperaceae) from Mexico. Contributions from the University of Michigan Herbarium 25: 225-230.

Rice PJ, Anderson TA, Coats JR. 1997. Phytoremediation of Herbicide-Contaminated Surface Water with Aquatic Plants, In: Kruger EL, Anderson TA \& Coats JR, eds. Phytoremediation of Soil and Water Contaminants. Washington: ACS Symposium Series, 133-151. DOI: 10.1021/bk-1997-0664

Rink G, Licher M. 2015. Vascular Plants of Arizona: Cyperaceae Sedge Family Part 1: Family Description, Key to the Genera, and Carex L. Canotia 11: 1-97.

Roalson EH. 1999. Eleocharis yecorensis (Cyperaceae), a new species of spike-sedge from Mexico. Aliso 18: 5760. DOI: 10.5642/aliso.19991801.15

Roalson EH. 2008. A Synopsis of Chromosome Number Variation in the Cyperaceae. Botanical Review 74: 209-393. DOI: 10.1007/s12229-008-9011-y

Rosen DJ. 2009. Eleocharis gonzaleziae (Cyperaceae), a New Species from Northern Mexico. Novon 19: 511-514. DOI: $10.3417 / 2007167$

Rosen DJ, Hatch SL, Carter R. 2007. Infraspecific taxonomy and nomenclature of Eleocharis acutangula (Cyperaceae). Journal of the Botanical Research Institute of Texas 1: 875-888.

Rosen DJ, Reid CS, González-Elizondo MS, Kral R. 2008a. Rediscovery of Fuirena repens (Cyperaceae), a rare endemic of the Mexican High Plateau. Acta Botanica Mexicana 85: 37-41. DOI: 10.21829/ abm85.2008

Rosen DJ, Hatch SL, Carter R. 2008b. Taxonomy and nomenclature of three closely related species of Eleocharis subg. Limnochloa (Cyperaceae). Blumea 53: 235-246. DOI: 10.3767/000651908X607936

Rzedowski J. 1991. El endemismo en la flora fanerogámica mexicana: una apreciación analítica preliminar. Acta Botanica Mexicana 15: 47-64. DOI: 10.21829/abm15.1991.620

Saarela JM, Peterson PM, González-Elizondo MS, Rosen DJ. 2010. Eleocharis cryptica (Cyperaceae), a dwarf new species from Durango, Mexico. Brittonia 62: 233-238. DOI: 10.1007/s12228-0099111-y

Simpson DA, Inglis CA. 2001. Cyperaceae of economic, ethnobotanical and horticultural importance: a checklist. Kew Bulletin 56: 257-360. DOI: 10.2307/4110962

Simpson D, Muasya AM, Alves M, Bruhl J, Dhooge S, Chase M, Furness L, Ghamkhar L, Goetghebeur P, Hodkinson T, Marchant A, Reznicek AA, Nieuwborg R, Roalson E, Smets E, Starr J, Thomas W, Wilson K, Zhang Z. 2007. Phylogeny of Cyperaceae based on DNA sequence data - a new rbc 1 analysis. Aliso 23: 72-83. DOI: 10.5642/aliso.20072301.09

Spalink D, Drew BT, Pace MC, Zaborsky JG, Starr JR, Cameron KM, Givnish TJ, Sytsma KJ. 2016. Biogeography of the cosmopolitan sedges (Cyperaceae) and the area-richness correlation in plants. Journal of Biogeography 43: 1893-1904. DOI:10.1111/jbi.12802

Squeo FA, Cavieres LA, Arancio G, Novoa JE, Matthei O, Marticorena C, Rodríguez R, Arroyo MTK, Muñoz M. 1998. Biodiversidad de la flora vascular en la región de Antofagasta, Chile. Revista Chilena de Historia Natural 71: 571-591.

Strong MT. 1993. New combinations in Schoenoplectus (Cyperaceae). Novon 3: 202-203. DOI: https:// doi.org/10.2307/3391535

Strong MT. 1994. Taxonomy of Scirpus, Trichophorum and Schoenoplectus (Cyperaceae) in Virginia. Bartonia 58: 29-68.

Strong M, González-Elizondo MS. 2000. Rhynchospora zacualtipanensis and Eleocharis moorei, two new Cyperaceae from Mexico. Sida 19: 115-122.

Strong MT. 2003. Cypringlea, a New Genus of Cyperaceae from Mexico. Novon 13: 123-132. DOI: $10.2307 / 3393577$

Svenson HK. 1929. Monographic studies in the genus Eleocharis. Rhodora 31: 121.242

Svenson HK. 1932. Monographic studies in the genus Eleocharis. Rhodora 34: 193-227.

Svenson HK. 1934. Monographic studies in the genus Eleocharis. Rhodora 36: 377-390.

Svenson HK. 1937. Monographic studies in the genus Eleocharis. Rhodora 39: 210-273.

Svenson HK. 1939. Monographic studies in the genus Eleocharis. Rhodora 41: 1-110.

Svenson HK. 1957. Eleocharis (Cyperaceae). North American Flora 18: 509-540.

Tena-Flores JA, González-Elizondo MS, Herrera-Arrieta Y, Almaraz-Abarca N, Mayek-Pérez N, da Silva CRM, Vanzela AL. 2013. Karyotype characterization of eight Mexican species of Eleocharis (Cyperaceae). Botanical Sciences 91: 119-128. DOI: 10.17129/botsci.408

Tena-Flores JA, González-Elizondo MS, Herrera-Arrieta Y, Almaraz-Abarca N, Mayek-Pérez N, Laforga-Vanzela AL. 2014. Karyotype characterization of four Mexican species of Schoenoplectus (Cyperaceae) and first report of polyploid mixoploidy for the family. Caryologia 67: 124-134. DOI:10.1080/0 0087114.2014 .931633

The Global Carex Group: Waterway MJ, Ford KA, Luceño M, Martín-Bravo S, Starr JR, Wilson KL, Yano O, Zhang SR, Roalson EH, Alverson WS, Bruederle LP, Bruhl JJ, Chung K-S, Cochrane TS, 
Escudero M, Ford BA, Gebauer S, Gehrke B, Hahn M, Hipp AL, Hoffmann MH, Hoshino T, JiménezMejías P, Jin X-F, Jung J, Kim S, Maguilla E, Masaki T, Míguez M, Molina A, Naczi RFC, Reznicek AA, Rothrock PE, Simpson DA, Spalink D, Thomas WW, Villaverde T. 2015. Making Carex monophyletic (Cyperaceae, tribe Cariceae): a new broader circumscription. Botanical Journal of the Linnean Society 179: 1-42. DOI:10.1111/boj.12298

The Global Carex Group: Jiménez-Mejías P, Hahn M, Lueders K, Starr JR, Brown BH, Chouinard BN, Kyong-Sook C, Escudero M, Ford BA, Ford KA, Gebauer S, Gehrke B, Hoffmann MH, Xiao-Feng J, Jung J, Kim S, Luceño M, Maguilla E, Martín-Bravo S, Míguez M, Molina A, Naczi RFC, Pender JE, Reznicek AA, Villaverde T, Waterway MJ, Wilson KL, Jong-Cheo Y, Zhang S, Hipp AL, Roalson EH. 2016. Megaphylogenetic specimen-level approaches to the Carex (Cyperaceae) phylogeny using ITS, ETS, and matK sequences: Implications for classification. Systematic Botany 41: 500-518. DOI: 10.1600/036364416X692497

The International Plant Names Index. 2017. Published on the Internet <www.ipni.org $>$ (accessed April $15,2017)$.

Thiers B. (continuously updated). Index Herbariorum: A global directory of public herbaria and associated staff. New York Botanical Garden's Virtual Herbarium. <sweetgum.nybg.org/science/ih/> (accessed July 15, 2016.

Thomas WW. 1984. The systematics of Rhynchospora section Dichromena. Memoirs of the New York Botanical Garden 37: 1-116.

Thomas WW. 1992. A synopsis of Rhynchospora (Cyperaceae) in Mesoamerica. Brittonia 44: 14-44. DOI: $10.2307 / 2807437$

Thomas WW. 1994. Rhynchospora, In: Davidse G, Sousa M, Chater A, eds. Flora Mesoamericana. Mexico City: Universidad Nacional Autónoma de México-Missouri Botanical Garden-The Natural History Museum, 404-422. ISBN: 968-36-3310-2

Tropicos.org (On Line). Missouri Botanical Garden, St. Louis, MO, USA. <www.tropicos.org> (accessed April 17, 2017).

Tucker GC. 1982. A New Species of Cyperus (Cyperaceae) from Costa Rica and Mexico. Systematic Botany 7: 345-347. DOI: $10.2307 / 2418394$

Tucker GC. 1986. New Mesoamerican species of Cyperus (Cyperaceae). Rhodora 88: 503-513.

Tucker GC. 1994. Revision of the Mexican species of Cyperus. Systematic Botany Monographs 43: 1-213. DOI: $10.2307 / 25027842$

Tucker GC, McVaugh R. 1993. Cyperus. In: Anderson W, Flora Novo-Galiciana. Ann Arbor: The University of Michigan Herbarium, 225-440.

Villaseñor JL. 2016. Checklist of the native vascular plants of Mexico. Revista Mexicana de Biodiversidad 87: 559-902. DOI: 10.1016/j.rmb.2016.06.017

Villaseñor JL, Ibarra-Manríquez G, Ocaña D. 1998. Strategies for the conservation of Asteraceae in Mexico. Conservation Biology 12: 1066-1075. DOI: 10.1046/j.1523-1739.1998.97171.x

Wang J, Xiao-yan L, Xin-ying Z, Zhen-zhen W, Zheng-nan C, Cheng-lin Z, Peng-cheng S. 2010. Phytoremediation potential of contaminated wetland of Cyperus rotundus for diesel contaminated wetland. Journal of Shanghai University (English Edition) 14: 326-331. DOI: 10.1007/s11741-010-0653-2 
Appendix 1. Checklist of Mexican Cyperaceae with state distribution and endemism level.

Numbers following the name of each genus indicate: (number of species in Mexico/endemic to the country/endemic to a state). Before species name: *en-

demic to the country, **endemic to a state. Number following author in some species indicate endemism to the Megamexico region (explanation in Methods

section) or to the Californian region: 1 (Mexico and southern United States), 2 (Mexico and Central America northern of the Nicaraguan depression), 3 (1 +

2), and 4 (Nortwestern Mexico and California).

States: Aguascalientes (Ags), Baja California (BC), Baja California Sur (BCS), Campeche (Cam), Ciudad de Mexico (CDM), Chiapas (Chis), Chihuahua

(Chih), Coahuila (Coah), Colima (Col), Durango (Dgo), Estado de Mexico (Mex), Guanajuato (Gto), Guerrero (Gro), Hidalgo (Hgo), Jalisco (Jal),

Michoacan (Mich), Morelos (Mor), Nayarit (Nay), Nuevo Leon (NL), Oaxaca (Oax), Puebla (Pue), Queretaro (Qro), Quintana Roo (QRoo), San Luis

Potosi (SLP), Sinaloa (Sin), Sonora (Son), Tabasco (Tab), Tamaulipas (Tam), Tlaxcala (Tlx), Veracruz (Ver), Yucatan (Yuc), Zacatecas (Zac).

Taxon

Distribution in Mexico

Abildgaardia (2/1/0)

*Abildgaardia mexicana (Palla) Kral

Abildgaardia ovata (Burm. f.) Kral

SLP, Zac

Amphiscirpus (1/0/0)

Amphiscirpus nevadensis (S. Wats.) Oteng-Yeb.

Bolboschoenus (2/0/0)

Bolboschoenus maritimus (L.) Palla in W. D. J. Koch subsp. paludosus

Bolboschoenus robustus (Pursh) Soják

Bulbostylis (14/3/2)

*Bulbostylis arcuata Kral

Bulbostylis barbata (Rottb.) C.B. Clarke

Bulbostylis capillaris (L.) C.B. Clarke

Bulbostylis funckii (Steud.) C.B. Clarke

Bulbostylis hispidula (Vahl) R.W. Haines in R.W.Haines \& K.A. Lye Bulbostylis junciformis (Kunth) C.B. Clarke

**Bulbostylis nesiotica (I. M. Johnst.) Fernald

Bulbostylis paradoxa (Spreng.) Lindm.

Bulbostylis pubescens (J. Presl \& C. Presl) Svenson

Bulbostylis schaffneri (Boeckeler) C.B. Clarke ${ }^{1}$

**Bulbostylis sepiacea Kral

Bulbostylis tenuifolia (Rudge) J. F. MacBr.

Bulbostylis trilobata Kral ${ }^{2}$

Bulbostylis vestita (Kunth) C.B. Clarke

Calyptrocarya (1/0/0)

Calyptrocarya glomerulata (Brongn.) Urb.

Carex (137/58/23)

Carex agrostoides Mack. ${ }^{1}$

*Carex albicans var. australis (L.H. Bailey) Rettig

Carex alma L.H. Bailey

Carex angustata Boott

**Carex angustispica Reznicek \& S. González

*Carex anisostachys Liebm.

*Carex arsenei Kük.

*Carex asynchrona Naczi

Carex athrostachya Olney

*Carex atractodes F. J. Herm.

Cam, Chis, QRoo, Tab, Tam, Ver, Yuc

Mex

BC, BCS, CDM, Chih, Coah, Col, Dgo, Mex, Mich, Sin, Son

Tab, Tam, Ver

Ags, BC, BCS, Chih, Dgo, Jal, Sin, Zac

QRoo?

Ags, BC, BCS, Cam, CDM, Chih, Chis, Coah, Col, Dgo, Gro, Gto, Hgo, Jal, Mex, Mich, Mor, Nay, NL, Oax, Pue, Qro, QRoo, Sin, SLP, Son, Tab, Tam, Tlx, Ver, Zac

Ags, CDM, Chih, Chis, Dgo, Gro, Hgo, Jal, Mex, Mich, Nay, NL, Oax, Qro, Pue, SLP, Son, Ver, Zac

BCS, Chis, Col, Jal, Nay, Oax, Ver

Chis, Col, Jal, Oax, Tab, Tam, Ver

Col

Chis, Oax, Ver

Chis, Gro, Jal, Mex, Mor, Nay, Oax, Sin, Son

Chih, Dgo, SLP

$\mathrm{Col}$

Chis, Hgo, Jal, Mich, Nay, Oax, Pue, Son, Tab, Ver

Chis, Oax, Ver

Cam, CDM, Chis, Col, Gro, Jal, Mex, Mich, Nay, Oax, QRoo, Sin, Ver

Cam, Chis, QRoo, Tab

Chih, Son

Hgo, Pue, Ver

BC, Chih, Son

$\mathrm{BC}$

Oax

Chis, CDM, Hgo, Mex, Mich, Oax, Qro, Pue, Ver

Jal, Mex, Mich

Chis, Qro, SLP, Tam

BC, Mich

Chis, SLP 
Appendix 1. Continuation.

Taxon

Distribution in Mexico

Carex aureolensis Steudel

Coah, NL

**Carex austromexicana Reznicek

Oax

*Carex aztecica Mack.

Chis, Mex, Oax

${ }^{* *}$ Carex ballsii Nelmes

Ver

Carex bartlettii O'Neill ${ }^{2}$

Cam, Chis, QRoo, Yuc

Carex bella L.H. Bailey ${ }^{1}$

$\mathrm{NL}$

Carex bolanderi Olney

Carex boliviensis van Heurck \& Müll. Arg. subsp. boliviensis

*Carex boliviensis van Heurck \& Müll. Arg. subsp. occidentalis

Reznicek \& S. González

Carex bonplandii Kunth

Chih, Dgo

CDM, Col, Dgo, Gro, Hgo, Jal, Mex, Mich, Oax, Pue

Chih, Dgo, Gro, Jal, Zac

Carex brachycalama Griseb.

Chis

Carex brevior (Dewey) Mack.

Mex

Tam

Carex bromoides Willd.

Carex brunnipes Reznicek ${ }^{2}$

Hgo

*Carex caeligena Reznicek

Chis, CDM, Hgo, Mex, Mor

Tam

Carex capitata L.

*Carex chiapensis F. J. Herm.

Chih, Son

Chis, Oax

Carex chordalis Liebm.

*Carex ciliaris Fernald

*Carex cochranei Reznicek

Chis, CDM, Gro, Hgo, Jal, Mex, Mich, Oax, Pue, Ver

Ags, Dgo, Hgo, Mex, Mich, Qro

Mex, Mich

Carex comosa Boott

${ }^{* *}$ Carex complanata Torr. \& Hook. subsp. tropicalis Reznicek \& S.

Hgo, Mex, Mich

González

Carex congestiflora Reznicek \& S. González²

Chis

*Carex conspecta Mack.

*Carex coulteri W. Boott ex Hemsl.

*Carex curviculmis Reznicek

Carex diandra Schrank

Carex distentiformis F. J. Herm. ${ }^{2}$

Carex donnell-smithii L.H. Bailey ${ }^{2}$

Carex douglasii Boott

**Carex durangensis Reznicek \& S. González

Carex eburnea Boott

Carex echinata Murray subsp. townsendii (Mack.) Reznicek²

Carex emoryi Dewey

Carex endlichii Kük. ${ }^{1}$

**Carex evadens S. González \& Reznicek

Chis

CDM, Pue, Ver

CDM, Gto, Hgo, Mex, Mich, Qro, SLP, Ver

Chis, CDM, Gto, Mex, Mich, Pue, Qro

$\mathrm{BC}$ ?

Hgo, Chis

Chis, Gro, Oax, Ver

BC

Dgo

Qro, SLP

Chih, Chis, CDM, Dgo, Mex, Mich, Mor, Oax, Pue, SLP, Ver

Chih, Coah

Chih, Dgo

Qro

Chih

**Carex festivelloides Reznicek

Chih

Carex firmula (Kük.) J.R. Starr

Oax

Oax

**Carex flexirostris Reznicek

BC

**Carex fructus Reznicek

Tam

Carex galeottiana C. Meyer

Chis, CDM, Hgo, Jal, Mex, Oax, Pue, Ver 
Appendix 1. Continuation.

Taxon

Distribution in Mexico

Carex geophila Mack. ${ }^{3}$

BCS, Chih, Chis, CDM, Hgo, Mex, Pue, Ver

Carex globosa Boott ${ }^{4}$

BC

Carex hamata Sw.

Carex hassei L.H. Bailey

Chis, CDM, Hgo, Mex, Mor, Oax, Tam, Ver

*Carex hermannii Cochrane

Carex huehueteca Standl. \& Steyerm.

BC

*Carex hultenii Aspl.

Carex humboldtiana Steud.

Carex hystericina Muhl.

Mex, Pue

Chis [no confirmado]

Chis, Hgo, Pue, Qro

Chis, CDM, Gro, Mex, Mich, Oax, Pue, Ver

Coah, Mex?, Ver

Carex interior L.H. Bailey

Chih

*Carex interjecta Reznicek

Mex, Mor

**Carex ixtapalucensis Reznicek

Carex kelloggii W. Boott var. kelloggii

Mex

Carex koyamae (Gómez-Laur.) J.R.Starr. ${ }^{2}$

Chih? Dgo, Mor, Son?

Chis, Oax

Carex laevivaginata (Kük.) Mack.

Mich

*Carex lagunensis M. E. Jones

Carex lativena S. D. Jones \& G. D. Jones ${ }^{1}$

BCS, Chih, CDM, Dgo, Mex, Mor

Carex leptalea Wahlenberg

*Carex leucodonta Holm.

*Carex longicaulis Boeckeler

Carex longii Mack.

**Carex longiligula Reznicek \& S. González

Coah

Chis

Chih, Dgo, Gto, Hgo, Jal, Mich, Nay, NL, Qro, Sin, Son, SLP, Son, Tam, Zac

Ags, CDM, Dgo?, Gto, Hgo, Jal, Mex, Mich, Mor, Oax, Pue, Tlx, Ver

Chis, CDM, Dgo, Hgo, Jal, Mex, Mich, Oax, Pue, Qro, SLP, Ver

Chis

**Carex longissima M. E. Jones

BCS

Carex lurida Wahlenb.

Chis, Hgo, Ver

**Carex mackenziana Weath.

*Carex madrensis L.H. Bailey

*Carex marianensis Stacey

**Carex mcvaughii Reznicek

$\mathrm{NL}$

Dgo, Gro, Jal, Mich, Mor, Qro, Ver

Chih, Chis, CDM, Dgo, Gro, Hgo, Jal, Mex, Mich, Mor, Oax, Son, Tlx

Jal

Carex meadii Dewey

Chih

Carex melanosperma Liebm. ${ }^{2}$

**Carex michoacana Reznicek, Hipp \& S. González

Chis, Mex, Mor, Pue, Tab, Ver

Mich

Carex microptera Mack.

Coah, Dgo, Mex

Carex muriculata F.J. Hermann ${ }^{1}$

Chih, Coah

Carex nigromarginata Schwein.

Pue

**Carex novogaliciana Reznicek

Jal

*Carex oaxacana L.H. Bailey

Chis, Oax

Carex occidentalis L.H. Bailey

Carex oreocharis Holm.

BC, Coah, Hgo?

Coah

Carex orizabae Liebm. ${ }^{2}$

CDM, Mex, Mich, Mor, Oax, Pue, Ver

Carex pellita Muhl. ex Willd.

*Carex percostata F. J. Herm.

BC, Chis?, Dgo, SLP

Chih, Dgo, Gro

Hgo, Oax, Ver

Coah, Hgo, NL, Qro, SLP, Tam

Chis, Tab, Ver 


\section{Appendix 1. Continuation.}

Taxon

Distribution in Mexico

Carex peucophila Holm. ${ }^{2}$

Carex phleoides Cav.

Ags, Chih, Chis, CDM, Gto, Hgo, Mex, Mich, Mor, NL?, Oax, Pue, Qro, SLP, Ver

**Carex pinophila Reznicek \& S. González

CDM

Carex planostachys Kunze ${ }^{3}$

Qro

Chih, Chis, Coah, CDM, Dgo, Gto, Mex, NL, Oax, Qro, SLP, Son?, Tab?, Tam, Tlx, Ver, Zac

Carex polystachya Sw. ex Wahlenb. var. polystachya

Carex polysticha Boeckeler

Cam, Chis, Col, CDM, Dgo, Gro, Hgo, Jal, Mex, Mich, Mor, Nay, Oax, Qro, SLP, Tam, Ver, Zac

Ver

*Carex potosina Hemsl.

Carex praegracilis W. Boott

*Carex pringlei L.H. Bailey

${ }^{* *}$ Carex pubig/uma Reznicek

**Carex queretarenesis Reznicek \& S. González

Carex quichensis F.J. Herm. ${ }^{2}$

*Carex rhynchoperigynium S. D. Jones \& Reznicek

Coah, NL, SLP, Zac

BC, BCS, Chih, Coah, CDM, Dgo, Hgo, Mex, Mich, Mor, Son

Coah, SLP

Chis

Qro

Oax

Hgo, NL, Qro

Carex rossii Boott

$\mathrm{BC}$

**Carex rzedowskii Reznicek \& S. González

Mich

*Carex schiedeana Kunze

Hgo, Pue, Qro, Ver

Carex schottii Dewey ${ }^{4}$

*Carex seatoniana L.H. Bailey

$\mathrm{BC}$

Carex senta Boott ex Olney ${ }^{1}$

Hgo, Jal?, Mex?, Oax, Pue

BC, Chih

Carex spilocarpa Steud. ${ }^{2}$

Carex spissa L.H. Bailey ${ }^{1}$

Chis, Hgo, Mex, Mor, Oax, Ver

BC

Carex standleyana Steyerm. ${ }^{2}$

*Carex stellata Mack.

Carex steyermarkii Standl. ${ }^{2}$

Carex subfusca W. Boott

**Carex tenejapensis Reznicek \& S. González

Chis, Oax, Ver

Coah, Gto, Hgo, NL, Qro, SLP, Tam, Zac

Chis

BC

Carex tetrastachya Scheele

Chis

Coah

Carex thurberi Dewey ${ }^{3}$

**Carex tolucensis (F. J. Herm.) Reznicek

Chih, Chis, Coah, Dgo, Jal, Son, Ver

Carex tribuloides Wahlenb. var. sangamonensis Clokey

Mex

Ver

Carex triquetra Boott ${ }^{4}$

$\mathrm{BC}$

*Carex tuberculata Liebm.

Carex tunimanensis Standl. \& Steyerm. ${ }^{2}$

*Carex turbinata Liebm.

Carex ultra L.H. Bailey ${ }^{1}$

CDM, Hgo, Mex, Pue

Chis

Ags, Chih, Coah, CDM, Dgo, Gto, Hgo, Jal, Mex, Mich, Mor, Nay, Oax, Pue, Sin, SLP, Son, Zac

Coah, Son

BC, Mor

*Carex vallicola var. hidalgensis F. J. Herm.

CDM, Hgo, Mex

**Carex vizarronensis Gómez-Sánchez, A. Cabrera L., S. González \& Qro

Reznicek

Carex vulpinoidea Michx.

Oax, Son, Ver

Carex wootonii Mack. ${ }^{1}$

Chih, Coah, Dgo, NL 
Appendix 1. Continuation.

Taxon

Distribution in Mexico

Carex xalapensis Kunth ${ }^{2}$

Chih, Chis, CDM, Dgo, Gto, Hgo, Mex, Mich, Oax, Qro, SLP, Tam, Ver

\section{Cladium (1/0/0)}

Cladium jamaicense Crantz subsp. jamaicense

Cladium jamaicense Crantz subsp. californicum (S. Watson)

Cyperus (113/19/8)

Cyperus acuminatus Torr. \& Hook.

Cyperus aggregatus (Willd.) Endl.

Cyperus amabilis Vahl var. amabilis

Cyperus andinus Palla ex Kük.

*Cyperus arsenei O'Neill \& Ben. Ayers.

Cyperus articulatus L.

*Cyperus aschenbornianus Boeckeler

Cyperus blepharoleptos Steud.

${ }^{* *}$ Cyperus breedlovei G. C. Tucker

Cyperus brevifolius (Rottb.) Endl. ex Hassk.

*Cyperus calderoniae S. González

Cyperus camphoratus Liebm.

Cyperus canus J. Presl \& C. Presl

Cyperus chorisanthos C.B. Clarke ${ }^{2}$

Cyperus ciliatus Jungh. ${ }^{2}$

Cyperus compressus L.

Cyperus conservator-davidii G.C. Tucker

Cyperus costaricensis Gómez-Laur.

Cyperus croceus Vahl

Cyperus cuspidatus Kunth

Cyperus dentoniae G. C. Tucker

Cyperus difformis L.

Cyperus digitatus Roxburgh

*Cyperus dioicus I. M. Johnst.

Cyperus dipsaceus Liebm. ${ }^{1}$

Cyperus distans L.f.

${ }^{* *}$ Cyperus duripes I. M. Johnst.

Cyperus elegans L.

Cyperus entrerianus Boeckeler

Cyperus eragrostis Lam.

Cyperus erythrorhizos Muhl.

Cyperus esculentus L.
Cam, Chis, Coah, Col, Hgo, NL, QRoo, SLP, Tab, Tam, Ver, Yuc

Coah, Son

Coah, NL, Tam

Ags, Cam, Chih, Chis, CDM, Coah, Col, Dgo, Gro, Gto, Hgo, Jal, Mex, Mich, Mor, Nay, NL, Oax, Pue, Qro, Sin, SLP, Son, Tab, Tam, Tlx, Ver, Yuc, Zac

BCS, Chih, Chis, Coah, Col, Dgo, Gro, Jal, Mex, Mich, Nay, Oax, Sin, SLP, Son, Ver

CDM, Dgo, Jal, Mex, Mich, SLP, Zac

BCS, CDM, Jal, Mex, Mich, Nay, Sin, Son

BCS, Cam, Chis, Col, CDM, Gro, Gto, Hgo, Jal, Mich, Mor, Nay, NL, Oax, Qro, QRoo, Sin, SLP, Son, Tab, Tam, Ver, Yuc, Zac

CDM, Jal, Mex, Mich, Mor, Nay, Oax, Ver

Cam, Chis, Gro, Gto, Jal, Mich, Nay, QRoo, Tab, Tam, Ver, Yuc

Chis

BC, Cam, Chis, Jal, Mich, Mor, Nay, NL, Oax, Pue, QRoo, Tab, Tam, Ver

CDM, Dgo, Gto, Hgo, Jal, Mex, NL, Qro, SLP, Zac

Chis, Gro, Oax, Tab, Ver

Chis, Col, Dgo, Gro, Hgo, Jal, Mex, Mich, Mor, Nay, NL, Oax, Qro, Sin, SLP, Son, Tab, Tam, Ver, Yuc

Cam, Chis, Oax

Chis, Gro, Oax, Ver

Cam, Chis, Col, Dgo, Gro, Jal, Mich, Nay, NL?, Oax, QRoo, Sin, Son, Tab, Tam, Ver, Yuc

Chis, Oax

Cam, Yuc

Cam, QRoo, Tab, Yuc

Chih, Chis, Dgo, Gro, Jal, Mex, Mor, Nay, Oax, SLP, Ver

Chih, Chis, Col, Dgo, Gro, Jal, Mich?, Nay, Oax, Sin, Son, Ver

Introduced: BTC, Chih, Dgo, Gto, Jal, Mich, Sin, Son

Cam, Chis, Col, Gro, Hgo, Jal, Mich, Nay, NL, Oax, Qro, QRoo, Sin, SLP, Tab, Tam, Ver, Yuc

BC, BCS

BCS, Chih, Dgo?, Nay, Sin, Son, Ver

Introduced: Chis, Gro

Col

Cam, Chis, QRoo, Yuc

BCS, Chis, Col, Dgo, Gto, Jal, Mich, Nay, Oax, Sin, SLP, Son, Tam, Ver, Zac

Coah, Mich, Oax

BC, BCS, Son, Tam, Tab

Ags, BC, BCS, Cam, Chih, Chis, CDM, Coah, Col, Dgo, Gro, Gto, Hgo, Jal, Mex, Mich, Mor, Nay, NL, Oax, Pue, Qro, QRoo, Sin, SLP, Son, Tab, Tam, Tlx, Ver, Yuc, Zac 


\section{Appendix 1. Continuation.}

Taxon

Cyperus fendlerianus Boeckeler

Cyperus flavescens L. var. piceus (Liebm.) Fernald

Cyperus flavicomus Michx.

Cyperus floribundus (Kük.) J. Rich. Carter \& S. D. Jones ${ }^{1}$

Cyperus fugax Liebm.

Cyperus gardneri Nees

Cyperus giganteus Vahl

Cyperus haspan L.

Cyperus hermaphroditus (Jacq.) Standl.

Cyperus hortensis (Salzm. ex Schltdl.) Dorr

Cyperus humilis Kunth

Cyperus hypopitys G.C. Tucker ${ }^{1}$

Cyperus imbricatus Retz.

Cyperus involucratus Rottb.

Cyperus iria L.

Cyperus ischnos Schltdl.

Cyperus laevigatus L.

Cyperus lanceolatus Poir.

Cyperus laxus Lam.

Cyperus lentiginosus Millsp. \& Chase

Cyperus leptocarpus (F. Muell.) Bauters

Cyperus ligularis L.

Cyperus lipomexicanus Goetgh.

Cyperus lundellii O’Neill

Cyperus luzulae (L.) Rottb. ex Retz.

Cyperus macrocephalus Liebm. var. eggersii (Boeckeler) S.D. Jones

Cyperus macrocephalus Liebm. var. macrocephalus

Cyperus manimae Kunth var. apiculatus (Liebm.) C.D. Adams

Cyperus manimae Kunth var. asperrimus (Liebm.) Kük.

Cyperus manimae Kunth var. divergens (Kunth) Kük. ${ }^{2}$

Cyperus manimae Kunth var. manimae

Cyperus manimae Kunth var. phaeocephalus (Griseb.) O'Neill \& Ben. Ayers

${ }^{* *}$ Cyperus matudae G. C. Tucker
Distribution in Mexico

BC, BCS, Chih, Coah, CDM, Dgo, Mex, Mich, NL, Qro, SLP, Son, Tlx, Tam

Ags, Chih, Chis, CDM, Coah, Col, Dgo, Gto, Gro, Hgo, Jal, Mex, Mich, Mor, Nay, NL, Oax, Pue, Qro, Sin, SLP, Son, Tam, Tlx, Ver, Zac

BC, Chih, Chis, Dgo, Gro, Gto, Jal, Mich, Nay, Oax, Sin, Son, Tam, $\mathrm{Zac}$

NL, SLP, Tam

Chih, Chis, Col, Dgo, Gro, Jal, Nay, Oax, Sin, Son, Ver

Cam, QRoo, Tab

Chis, Col, Jal, Oax, QRoo, Tab, Tam, Ver

BCS, Cam, Chis, Gro, Jal, Mich, Nay, Oax, Sin, Tab, Tam, Ver, Yuc

Ags, BC, BCS, Cam, Chih, Chis, CDM, Coah, Col, Dgo, Gro, Gto, Hgo, Jal, Mex, Mich, Mor, Nay, NL, Oax, Pue, Qro, QRoo, Sin, SLP, Son, Tab, Tam, Tlx, Ver, Zac

Introduced: Cam, Chis, CDM, Gro, Hgo, Jal, Mex, Mich, Mor, Nay, Oax, Pue, Qro, SLP, Tab, Tam, Ver, Yuc

Cam, Chis, Dgo, Gro, Oax, Qro, QR, SLP, Tab, Tam, Ver

Chih, Dgo, Sin, Son

Chis, Col, Gro, Jal, Mich, Nay, Tab, Ver

Introduced: BC, Chih, Chis, Col, CDM, Jal, Mor, NL, Oax, Qro, Sin, Son, Tab, Tam, Ver, Yuc

Introduced: Cam, Chih, Chis, Col, Dgo, Gro, Jal, Mich, Nay, Oax, QRoo, Sin, SLP, Son, Tab, Tam, Ver

Chih, Chis, Dgo, Gro, Jal, Mex, Mich, Nay, Oax, Sin, Son, Ver Introduced: Ags, BC, BCS, Cam, Chih, Chis, CDM, Coah, Col, Dgo, Gro, Gto, Hgo, Jal, Mex, Mich, NL, Oax, Pue, Qro, Sin, SLP, Son, Tab, Tam, Tlx, Ver, Yuc, Zac

BC, BCS, Cam, Chih, Chis, Col, Dgo, Gro, Hgo, Jal, Mich, Mor, Nay, NL, Oax, Pue, QRoo, Sin, SLP, Son, Tam, Ver

Chis, Gro, Jal, Mex, Mich, Mor, Nay, Oax, Tab, Tam, Ver

Cam, Chis, Gro, QRoo, SLP, Tam, Ver, Yuc

Introduced: Chis

BCS, Cam, Chis, Col, Dgo, Gro, Jal, Mich, Nay, Oax, QRoo, Sin, Son, Tab, Tam, Ver, Yuc

Chis, Dgo, Gro, Jal, Nay, Oax, Ver

Cam, Chis, QRoo, Tam

Cam, Chis, Mich, Nay, Oax, QRoo, Sin, SLP, Tab, Tam, Ver, Yuc

Cam, Tab, Tam, Ver, Yuc

Cam, Chis, Gro, QRoo, Tab, Ver, Yuc

Mex

BCS, Chih, Chis, Coah, CDM, Dgo, Hgo, Jal, Mex, Mich, Mor, Nay, Oax, Pue, SLP, Son, Tam, Ver

Chih, Chis, Coah, CDM, Dgo, Gro, Gto, Hgo, Jal, Mex, Mich, Pue, Qro, Son, Ver

Ags, BCS, Chih, Chis, Coah, CDM, Dgo, Mex, Gro, Gto, Hgo, Jal, Mex, Mich, Mor, Nay, NL, Oax, Pue, Qro, Sin, SLP, Son, Tam, Tlx, Ver, Zac

CDM, Dgo, Mex, Hgo, Pue, Ver.

Chis 


\section{Appendix 1. Continuation.}

Taxon

*Cyperus michoacanensis Britton ex C.B. Clarke

Cyperus microbrunneus G. C. Tucker

Cyperus mutisii (Kunth) Griseb. var. asper (Liebm.) Kük.

Cyperus mutisii (Kunth) Griseb. var. mutisii

*Cyperus nayaritensis G. C. Tucker

Cyperus niger Ruiz \& Pav. var. capitatus (Britton) O'Neill

Cyperus niger Ruiz \& Pav. var. niger

Cyperus ochraceus Vahl

Cyperus odoratus L.

Cyperus oxylepis Nees ex Steud.

Cyperus pallidicolor (Kük.) G. C. Tucker

Cyperus panamensis (C. B. Clarke) Britton ex Standl.

Cyperus papyrus L.

Cyperus parishii Britton ${ }^{1}$

Cyperus pedunculatus (R. Br.) J. Kern

**Cyperus penicillatus Conz.

Cyperus pennellii O'Neill \& Ben. Ayers.

*Cyperus perennis (M. E. Jones) O'Neill

Cyperus planifolius Rich.

Cyperus polystachyos Rottb.

Cyperus prolixus Kunth

Cyperus pseudothyrsiflorus (Kük.) J. Rich. Carter \& S.D. Jones ${ }^{1}$

Cyperus pseudovegetus Steud. var. megalanthus Kük. ${ }^{2}$

*Cyperus pycnostachyus (Kunth) Kunth

Cyperus reflexus Vahl

Cyperus regiomontanus Britton ${ }^{3}$

Cyperus retroflexus Buckley

Cyperus retroflexus Buckley var. pumilus ${ }^{1}$

Cyperus retrorsus Chapm.

Cyperus rotundus L.

Cyperus salzmannianus (Steud.) Bauters

**Cyperus sanguineo-ater Boeckeler var. floribundus Kük.

Cyperus sanguineo-ater Boeckeler var. sanguineo-ater

*Cyperus schaffneri Boeckeler

Cyperus schweinitzii Torr.

Cyperus semiochraceus Boeckeler ${ }^{2}$

Cyperus seslerioides Kunth
Distribution in Mexico

Jal, Mich

Chis, Oax

Col, Jal, Mex, Nay, Pue, Sin, Son, Ver

Ags, BCS, Chih, Chis, CDM, Dgo, Gro, Hgo, Jal, Mex, Mich, Mor, Nay, NL, Oax, Pue, Qro, QRoo, Sin, Son, Tlx, Ver, Zac

Col, Jal, Mich, Nay

BC, BCS, Chih, Jal, Son, Tam

Ags, BC, BCS, Chih, Chis, Coah, CDM, Dgo, Gro, Gto, Hgo, Jal, Mex, Mich, Mor, NL, Oax, Pue, Qro, QRoo, SLP, Sin, Son, Tab, Tam, Tlx, Ver, Zac

Cam, Chis, Coah, Col, Gro, Hgo, Jal, Mex, Mich, Mor, Nay, NL, Oax, Pue, Qro, QRoo, Sin, SLP, Son, Tab, Tam, Ver, Yuc, Zac

Ags, BC, BCS, Cam, Chis, Chih, CDM, Coah, Col, Dgo, Gro, Gto, Hgo, Jal, Mex, Mich, Mor, Nay, NL, Oax, Pue, Qro, QRoo, Sin, SLP, Son, Tab, Tam, Ver, Yuc, Zac

Introduced: Chis, Col, Gro, Oax, Sin, Son, Tam

Ags, BC, BCS, Chih, Chis, Coah, CDM, Dgo, Hgo, Jal, Mex, Mich, Mor, Nay, NL, Oax, Pue, Son, Tlx, Ver, Zac

Chis, Gro, Oax, Sin, Ver

Introduced: Mich, Mor, Ver

Son

QRoo, Yuc

Oax

Dgo, Mex, Mich

BC, BCS, Son

Cam, QRoo, Yuc

Cam, Chis, Gro, Oax, QRoo, Son, Tab, Tam, Ver, Yuc

Chis, CDM, Dgo, Hgo, Jal, Mex, Mich, Nay, Oax, Sin, Son, Tam, Ver NL, Qro

Cam, Chis, Qro, QRoo, SLP, Tam, Ver, Yuc

CDM, Mex, Mich, Pue, Tlx

CDM, Gto, Hgo, Jal, Mex, Mich, Qro, SLP, Ver

Chis, Col, Gro, Jal, Oax, Mich, Sin, Son

Chih, Coah, NL, Qro, Sin, Son, Tab, Tam, Ver

Tab

Tam

BCS, Cam, Chih, Chis, Col, CDM, Dgo, Gto, Gro, Hgo, Jal, Mex, Mich, Mor, Nay, NL, Oax, Pue, Qro, QRoo, SLP, Sin, SLP, Son, Tab, Tam, Ver, Yuc, Zac

Ver

Mor

Chih, CDM, Dgo, Gro, Gto, Jal, Mex, Mich, Mor, Nay, Pue, Qro, Oax, Sin, Son, Zac

CDM

Chih, Dgo

BCS, Chih, CDM, Gro, Gto, Jal, Mex, Mich, Mor, Nay, Oax, Pue, Son, Ver

Ags, Chih, Chis, CDM, Dgo, Gro, Gto, Hgo, Jal, Mex, Mich, Mor, Nay, Oax, Pue, Qro, Sin, SLP, Son, Tlx, Ver, Yuc, Zac 


\section{Appendix 1. Continuation.}

Taxon

Cyperus sesquiflorus (Torr.) Mattf. \& Kük.

Cyperus simplex Kunth

*Cyperus sordidus J. Presl \& C. Presl

Cyperus spectabilis Link

*Cyperus spectabilis Link var. parryi (C. B. Clarke) Kük.

Cyperus sphaerolepis Boeckeler ${ }^{1}$

Cyperus squarrosus L.

Cyperus subsquarrosus (Muhl.) Bauters

Cyperus surinamensis Rottb.

Cyperus svensonii G. C. Tucker ${ }^{2}$

Cyperus swartzii (A. Dietr.) Boeckeler ex Kük.

*Cyperus tempeae G. C. Tucker

Cyperus tenerrimus J. Presl \& C. Presl

Cyperus tenuis Sw.

Cyperus thyrsiflorus Jungh.

Cyperus trachynotus Torr. ${ }^{1}$

Cyperus uncinulatus Schrad. ex Nees

Cyperus unioloides $\mathrm{R}$. Br.

Cyperus virens Michx. var. drummondii (Torr. \& Hook.) Kük. Cyperus virens Michx. var. minarum (Boeckeler) Denton Cyperus virens Michx. var. virens

${ }^{* *}$ Cyperus wilburii G. C. Tucker

**Cyperus sp. [Kyllinga microcephala Liebm. non Steud.]

Cypringlea (3/3/0)

*Cypringlea analecta (Beetle) M. T. Strong

*Cypringlea coahuilensis (Svenson) M. T. Strong

*Cypringlea evadens (C.D. Adams) Reznicek et S. González

Eleocharis (55/10/5)

Eleocharis acicularis (L.) Roem. \& Schult.

Eleocharis acutangula (Roxb.) Schult. subsp. acutangula

Eleocharis acutangula (Roxb.) Schult. subsp. breviseta D.J. Rosen

Eleocharis albibracteata Nees \& Meyen ex Kunth

Eleocharis albida Torr. ${ }^{3}$

**Eleocharis arsenifera S. González, J. Tena et T. Alarcón

Eleocharis atropurpurea (Retz.) J. Presl \& C. Presl

Eleocharis bella (Piper) Svenson
Distribution in Mexico

Chis, Col, CDM, Dgo, Gro, Gto, Hgo, Jal, Mex, Mich, Mor, Nay, Oax, Qro, Pue, SLP, Sin, Son, Tam, Tlx, Ver

Chis, Oax

Col, Gro, Jal, Nay, Sin

Ags, Chih, Chis, CDM, Coah, Col, Dgo, Gro, Gto, Hgo, Jal, Mex, Mich, Mor, Nay, NL, Oax, Pue, Qro, Sin, SLP, Tam, Ver, Zac

CDM, Gto, Mex, SLP

Ags, Chih, Coah, CDM, Dgo, Gto, Hgo, Jal, Mex, NL, Pue, Qro, SLP, Son, Tlx, Zac

Ags, BC, BCS, Cam, Chih, Chis, Coah, CDM, Dgo, Gro, Gto, Jal, Mex, Mich, Mor, NL, Oax, Pue, Qro, QRoo, Sin, SLP, Son, Tab, Tam, Tlx, Ver, Yuc, Zac

BC, BCS, Chih, Chis, Col, Dgo, Gro, Jal, Mex, Mich, Mor, Nay, Oax, Pue, Sin, SLP, Son, Tam, Tlx, Ver, Zac

Ags, BCS, Cam, Chis, Col, Dgo, Gro, Gto, Jal, Mex, Mich, Mor, Nay, Oax, Pue, Qro, QRoo, Sin, SLP, Son, Tab, Tam, Ver, Yuc

Chis

SLP, Ver

SLP, Tam, Ver

Chis, Col, Dgo, Gro, Jal, Mex, Mich, Mor, Nay, Oax, Pue, Sin, Son, Ver

BC, BCS, Cam, Chis, Mex, Mich, Nay, Oax, Pue, Qro, QRoo, SLP, Son, Tab, Ver, Yuc

Cam, Chis, Coah, Hgo, Mich, Mor, Nay, NL, Oax, Pue, QRoo, SLP, Tab, Tam, Ver

BC, BCS, Col, Gro, Jal, Mich, Nay, NL, Oax, Pue, Qro, SLP, Sin, Son, Tab, Tam, Ver

Chis, Oax

Chis, CDM, SLP, Tab, Oax, Ver

Dgo

Chis, Mex

Ags, Chis, CDM, Coah, Col, Dgo, Gto, Hgo, Jal, Mex, Mich, Nay, Oax, Qro, SLP, Son, Tab, Ver, Zac

Oax

Ver

Hgo, NL, Qro, SLP, Tam

Coah, NL

Chis, Gro, Oax, Pue

Ags, BC, Chih, Chis, CDM, Dgo, Gto, Hgo, Jal, Mex, Mich, Mor, Oax, Pue, Qro, SLP, Ver, Zac

Chis, Hgo, Jal, Nay, Oax, Tab, Tam, Ver, Yuc

Cam, Chis, Gro

Chis, Gro

Tam, Yuc

Chih

Cam, Chis, Dgo, Gro, Jal, Oax, Son, Yuc

BC, Chih, Dgo, Son 
Appendix 1. Continuation.

Taxon

Eleocharis bonariensis Nees

Eleocharis brachycarpa Svenson ${ }^{1}$

Eleocharis cancellata S. Watson ${ }^{1}$

Eleocharis cellulosa Torr.

Eleocharis coloradoensis (Britton) Gilly

**Eleocharis cryptica Saarela, P.M. Peterson, S. González \& D.J. Rosen Eleocharis densa Benth. ${ }^{2}$

Eleocharis dombeyana Kunth

Eleocharis elegans (Kunth) Roem. \& Schult.

Eleocharis elongata Chapm.

Eleocharis filiculmis Kunth

Eleocharis flavescens (Poir.) C.B. Clarke

Eleocharis geniculata (L.) Roem. \& Schult.

**Eleocharis gonzaleziae D.J. Rosen

*Eleocharis ignota S. González \& Reznicek

Eleocharis interstincta (Vahl) Roem. \& Schult.

Eleocharis macrostachya Britton

Eleocharis maculosa (Vahl) R. Br.

Eleocharis minima Kunth

Eleocharis minutissima Britton

Eleocharis montana (Kunth) Roem. \& Schult.

Eleocharis montevidensis Kunth

*Eleocharis moorei M. Strong \& S. González

Eleocharis mutata (L.) Roem. \& Schult.

Eleocharis nigrescens (Nees) Steud.

Eleocharis obtusetrigona (Lindl. \& Nees) Steud.

Eleocharis pachystyla (C. Wright) C.B. Clarke

Eleocharis palustris (L.) Roem. \& Schult.

Eleocharis parishii Britton

Eleocharis parvula (Roem. \& Schult.) Link ex Bluff, Nees \& S. Schauer.

Eleocharis plicarhachis (Griseb.) Svenson

Eleocharis quinqueflora (Hartmann) O. Schwarz

Eleocharis quinqueflora (Hartmann) O. Schwarz var. bernardina (Munz \& I.M. Johnst.) S. González \& P.M. Peterson ${ }^{4}$

Eleocharis radicans (A. Dietr.) Kunth

Eleocharis ravenelii Britton ${ }^{1}$

Eleocharis retroflexa (Poir.) C.B. Clarke

*Eleocharis reznicekii S. González, D.J. Rosen, R. Carter \& P.M.

Peterson
Distribution in Mexico

CDM, Dgo, Mex, Mich, Oax, Qro

Tam

Chih, CDM, Gto, Mex, SLP

Cam, Chis, Coah, Gro, Jal, Nay, NL, QRoo, Tab, Tam, Ver, Yuc

BC, Coah, Chih, Dgo, Sin, Tam, Ver

Dgo

Ags, Chis, CDM, Dgo, Gto, Hgo, Jal, Mex, Mich, Mor, Oax, Pue, Qro, SLP, Ver, Zac

Chis, CDM, Coah, Dgo, Hgo, Jal, Mex, Mich, Mor, Oax, Pue, SLP, Son, Ver, Zac

Cam, Chis, Col, Gro, Gto, Hgo, Jal, Mex, Mich, Mor, Nay, Oax, Pue, Qro, QRoo, Sin, SLP, Son, Tab, Tam, Ver, Yuc

Cam?, Yuc?

Cam, Chis, Gto, Gro, Jal, Mor, Oax, Pue, Qro, QRoo, Tab, Ver

BCS, Coah, Chis, Jal, Mor, SLP, Son, Tam, Ver

Ags, BC, BCS, Cam, Chih, Chis, CDM, Coah, Col, Dgo, Gro, Gto, Hgo, Jal, Mex, Mich, Mor, NL, Oax, Pue, Qro, QRoo, Sin, SLP, Son, Tab, Tam, Tlx, Ver, Yuc, Zac

Dgo

Dgo, Gto, Jal, Mich, Zac

Cam, Chis, Col, Tab, Tam, Ver, Yuc

Ags, BC, Chih, Chis, Coah, CDM, Dgo, Gto, Hgo, Jal, Mex, Mich, Mor, NL, Oax, Pue, Qro, Sin, SLP, Son, Tam, Zac

Chis

Cam, Chis, Dgo, Gro, Jal, Mich, Nay, Oax, Qro, QRoo, Sin, Tab, Tam, Ver

Cam, Chis, Oax, QRoo

Ags, Cam, Chis, Coah, CDM, Dgo, Gro, Gto, Hgo, Jal, Mex, Mich, Mor, Nay, Oax, Pue, Qro, QRoo, SLP, Son, Ver, Yuc, Zac

Ags, BC, BCS, Chih, Chis, Coah, CDM, Dgo, Gro, Gto, Hgo, Jal, Mex, Mich, Mor, Oax, Pue, Qro, SLP, Son, Tam, Tlx, Ver, Zac

Hgo, Ver

Cam, Chis, Coah, Col, Gro, Jal, Nay, QRoo, Sin, Tab, Tam, Ver, Yuc

Ags, Cam, Chis, Jal, QRoo, Tab, Ver, Yuc

Ver

Chis, Oax, Tab, Ver

$\mathrm{BC}$

Ags, BC, BCS, Chih, Coah, Dgo, NL, Son, Zac

BC, Cam, Chis, Tab, Ver

Cam, Chis, Tab, Yuc

$\mathrm{BC}$

$\mathrm{BC}$

BC, Chih, Chis, Coah, Dgo, Gro, Mex, Mich, Oax, Son, Tab, Tam, Ver SLP, Tam?

Cam, Chis, Oax, Tab, Ver

Ags, Dgo, Gto, Zac 


\section{Appendix 1. Continuation.}

Taxon

Eleocharis rostellata (Torr.) Torr.

**Eleocharis rzedowskii S. González

Eleocharis schaffneri Boeckeler

Eleocharis sellowiana Kunth

**Eleocharis subcancellata C.B. Clarke

*Eleocharis svensoniana S. González

*Eleocharis tenarum S. González \& M. González E.

Eleocharis tiarata Gómez-Laur.

Eleocharis urceolata (Liebm.) Svenson

Eleocharis xyridiformis Fernald \& Brackett

Eleocharis yecorensis E. Roalson ${ }^{2}$

Fimbristylis (16/2/0)

Fimbristylis annua (Allioni) Roem. \& Schult.

*Fimbristylis argillicola Kral

Fimbristylis autumnalis (L.) Roem. \& Schult.

Fimbristylis caroliniana (Lam.) Fernald

Fimbristylis castanea (Michaux) Vahl

Fimbristylis complanata (Retz.) Link

Fimbristylis cymosa R. Br.

Fimbristylis dichotoma (L.) Vahl

Fimbristylis ferruginea (L.) Vahl

Fimbristylis littoralis Gaudich.

*Fimbristylis pentastachya Boeckeler

Fimbristylis puberula (Michx.) Vahl

Fimbristylis quinquangularis (Vahl) Kunth

Fimbristylis spadicea (L.) Vahl

Fimbristylis thermalis S. Watson ${ }^{1}$

Fimbristylis vahlii (Lam.) Link

Fuirena (7/3/1)

Fuirena camptotricha C. Wright

Fuirena incompleta Nees var. incompleta

*Fuirena incompleta Nees var. obliterata Kral

*Fuirena repens Boeckeler

Fuirena robusta Kunth

*Fuirena simplex Vahl var. aristulata (Torr.) Kral

Fuirena simplex Vahl var. simplex

**Fuirena stephani Ramos \& N. Diego

Fuirena umbellata Rottb.

Hypolytrum (1/0/0)

Hypolytrum nicaraguense Liebm.
Distribution in Mexico

BC, Chih, Chis, Coah, Dgo, Mich, NL, Pue, Son, Tam, Zac

NL

Ags, Chih, Chis, Dgo, Gto, Jal, Mich, Oax, Qro, SLP, Zac

Chis

Jal

Chih, Dgo, Jal, Sin, Son

Ags, Dgo, Gto, Mex, Qro, Zac

Cam

Cam, Chis, Ver

CDM, Dgo, Mex, Zac

Dgo, Gto, Jal, Mex, Nay, Son, Zac

Ags, BC, Cam, CDM, Chih, Dgo, Gro, Gto, Jal, Mex, Mich, Nay, Pue, Qro, QRoo, Sin, Son, Tab, Ver, Zac

Ags, CDM, Dgo, Gro, Gto, Jal, Mex, Mich, Pue, Zac

Chis, Oax, Sin, SLP, Tab, Ver

Tab, Tam, Ver

Tam, QRoo, Yuc

BCS, Cam, Chih, Chis, Dgo, Gro, Jal, Mex, Mich, Nay, NL, Oax, Pue, SLP, Son, Tab, Tam, Ver, Yuc

Cam, Chis, Col, Gro, Jal, Mich, Nay, Oax, QRoo, Sin, Son, Tab, Tam, Ver, Yuc

Ags, BC, BCS, Cam, Chis, Chih, Dgo, Gto, Gro, Jal, Mex, Mich, Nay, Oax, Qro, Sin, Son, Tab, Tam, Ver, Yuc

Cam, QRoo, Yuc

Cam, Col, Chis, Gro, Jal, Mex, Mich, Mor, Nay, NL, Oax, Sin, SLP, Tab, Ver

Gro, Jal, Mich, Nay, Oax, Sin, Son, Ver

Cam, Chih, SLP, Tam

Dgo, Jal, Nay, Oax, Sin

Cam, Chis, Coah, Col, Gro, Jal, Mex, Mich, Nay, Oax, QRoo, Sin, Tab, Tam, Ver, Yuc

BC, Chih, Coah, SLP, Son

BC, Chis, NL, Son, Tab, Tam

Cam, Chis, QRoo, Tab, Ver, Yuc

Chis, Dgo, Mex, Mich, Ver

Dgo, Gto, Jal, Mex, Nay, Son

Dgo, Qro, SLP

Cam, Tab

BC, Son

BC, BCS, Cam, Chih, Chis, Coah, Dgo, Gro, Hgo, Jal, Mex, Mor, NL, Oax, Pue, Qro, Sin, SLP, Son, Tab, Tam, Ver, Yuc

Cam

Tab, Yuc

Chis, Oax, Tab, Ver 
Isolepis $(2 / 0 / 0)$

Isolepis carinata Hook. \& Arn. ex Torr.

Isolepis cernua (Vahl) Roem. \& Schult.

Karinia (1/1/0)

*Karinia mexicana (C.B. Clarke,ex Britton) Reznicek \& McVaugh

Rhynchospora (63/7/3)

**Rhynchospora angosturensis W. W. Thomas

Rhynchospora aristata Boeckeler var. aristata

*Rhynchospora aristata Boeckeler var. suberecta Kük.

Rhynchospora barbata (Vahl) Kunth

Rhynchospora berteroi (Spreng.) C.B. Clarke

Rhynchospora boliviensis C.B. Clarke

Rhynchospora brevirostris Griseb.

Rhynchospora brittonii Gale

Rhynchospora brownii Roem. \& Schult. subsp. americana Guagl.

Rhynchospora cephalotes (L.) Vahl

Rhynchospora ciliata (G. Mey.) Kük.

Rhynchospora colorata (L.) H. Pfeiff.

Rhynchospora consanguinea (Kunth) Boeckeler

Rhynchospora contracta (Nees) J. Raynal

Rhynchospora corymbosa (L.) Britton

Rhynchospora divergens Chapm. ex M. A. Curtis

Rhynchospora dives Standl. ${ }^{2}$

*Rhynchospora durangensis Kral \& W. W. Thomas

Rhynchospora eximia (Nees) Boeckeler

Rhynchospora fascicularis (Michx.) Vahl

Rhynchospora filifolia A. Gray

Rhynchospora filiformis Vahl

Rhynchospora floridensis (Britton ex Small) H. Pfeiff.

Rhynchospora gigantea Link

Rhynchospora globosa (Kunth) Roem. \& Schult.

Rhynchospora globularis (Chapm.) Small var. recognita Gale

Rhynchospora gracilenta A. Gray

Rhynchospora harveyi W. Boott. var. harveyi

Rhynchospora hassleri C.B. Clarke

Rhynchospora hirsuta (Vahl) Vahl

Rhynchospora holoschoenoides (Rich.) Herter

Rhynchospora inundata (Oakes) Fern.

*Rhynchospora jaliscensis McVaugh

*Rhynchospora jubata Liebm.

Rhynchospora kunthii Nees ex Kunth

Rhynchospora lindeniana Griseb. var. bahamensis (Britton) Gale

Rhynchospora marisculus Lindl. \& Nees ex Nees
$\mathrm{BC}$ ?

BC, BCS, Son

Ags, CDM, Dgo, Gto, Jal, Mex, Mich, Qro, Pue, SLP, Zac

SLP

Chis, CDM, Hgo, Jal, Mex, Oax, Ver

Dgo, Mex, Gro, Jal, Mich, Nay, Oax

Cam, Chis, QRoo, Tab, Ver

Cam, QRoo, Yuc?

Oax

Chis, Gro, Jal, Mich, Mor, Nay, Oax

$\mathrm{Tab}$

Chis

Cam, Chis, Gro, Oax, Tab, Ver, Yuc

Cam, Chis, Oax, QRoo, Tab, Ver, Yuc

Cam, Chis, CDM, Coah, Col, Dgo, Gro, Jal, Mex, Mor, NL, Oax, Qro, QRoo, SLP, Tab, Tam, Ver, Yuc

Chis, Oax, Tab, Ver

Cam, Chis, Dgo, Gro, Jal, Mex, Nay, Oax, QRoo, Sin, Tab, Ver, Yuc

Cam, Chis, Tab, Ver

Chis

Chis, Tab, Ver

Dgo, Zac

Cam, Chis, Col, Gro, Jal, Nay, Tab, Ver

Cam, Tab, Ver

$\mathrm{Tab}$

Cam, Chis, Tab, QRoo

Cam, Chis, Oax, QRoo, Yuc

Cam, Tab, Ver

Cam, Chis, Oax, QRoo, Tab, Ver

Chis

Chis

Coah

Ver

Cam, Chis, Tab

Cam, Chis, Jal, Nay, Oax, QRoo, Tab, Ver, Yuc

$\mathrm{Tab}$

Dgo, Jal

Chis, Tab, Ver

Chih, Chis, CDM, Dgo, Gro, Hgo, Jal, Mex, Mich, Nay, Oax, Pue, SLP, Tab, Ver

QRoo, Yuc

Chis, Ver 


\section{Appendix 1. Continuation.}

Taxon

Rhynchospora marliniana Naczi, W. M. Knapp \& W.W. Thomas Rhynchospora mexicana (Liebm.) Steud.

Rhynchospora nervosa (Vahl) Boeckeler

Rhynchospora cf. nitens (Vahl) A. Gray

Rhynchospora nivea Boeckeler ${ }^{1}$

Rhynchospora oligantha A. Gray

Rhynchospora plumosa Elliott

Rhynchospora polyphylla (Vahl) Kunth

Rhynchospora pusilla Chapm. ex M. A. Curtis

Rhynchospora radicans (Schltdl. \& Cham.) H. Pfeiff. subsp.

microcephala (Bertero ex Spreng.) W. W. Thomas

Rhynchospora radicans (Schltdl. \& Cham.) H. Pfeiff. subsp. radicans

Rhynchospora robusta (Kunth) Boeckeler

**Rhynchospora rosae W.W. Thomas

Rhynchospora rugosa (Vahl) Gale

Rhynchospora ruiziana Boeckeler

Rhynchospora schiedeana Kunth

Rhynchospora scutellata Griseb.

Rhynchospora tenerrima Nees ex Spreng.

Rhynchospora tenuis Link

Rhynchospora tracyi Britton

Rhynchospora triflora Vahl

Rhynchospora trispicata (Nees) Schrad. ex Steud.

Rhynchospora tuerckheimii C.B. Clarke ex Kük.

Rhynchospora velutina (Kunth) Boeckeler

Rhynchospora vulcani Boeckeler

Rhynchospora watsonii (Britton) Davidse

**Rhynchospora zacualtipanensis M. Strong

Schoenoplectiella (2/0/0)

Schoenoplectiella erecta (Poir.) Lye

Schoenoplectiella saximontana (Fernald) Lye

Schoenoplectus (5/0/0)

Schoenoplectus acutus (Muhlenberg ex Bigelow) Á. Löve \& D. Löve var. occidentalis (S. Watson) S. G. Smith

Schoenoplectus americanus (Pers.) Volkart ex Schinz et R. Keller

Schoenoplectus californicus (C. A. Meyer) Soják

Schoenoplectus pungens (Vahl) Palla

Schoenoplectus tabernaemontani (C. C. Gmelin) Palla

Schoenus (1/0/0)

Schoenus nigricans L.

Scirpus (4/0/0)

Scirpus atrovirens Willd.

Scirpus cyperinus (L.) Kunth
Distribution in Mexico

Tab

Chis, Jal, Oax

Cam, Chis, Gro, Jal, Mex, Nay, Oax, QRoo, SLP, Sin, Tab, Tam, Ver Yuc

Coah

Cam

QRoo, Tab

Chis, Ver

Chis, Tab

Chis, Gro, QRoo, Tab, Ver, Yuc

Cam, Chis, Hgo, Oax, Pue, Qro, QRoo, SLP, Tab, Ver

Chis, Tab, Ver [Pendiente]

Chis

Chis, Oax, Tab, Ver

Chis, Oax

Chis, Ver

Cam, Gro, Mich, Tab, Yuc

Cam, Chis, Tab

Cam, Chis, Jal, Nay, Sin, Ver

Yuc

Cam

Cam, Chis, Tab, Ver

Chis, Gro, Ver

Cam, Chis, Tab, Ver

Chis

Cam, Chis, QRoo, Tab, Ver

Hgo

NL, QRoo, Tam, Yuc

BC, BCS, Chih, Coah, NL, Qro, SLP, Tam

Ags, BC, Chih, Coah, Dgo, Mich, NL, Son, Zac

Ags, BC, BCS, Chih, Chis, CDM, Coah, Col, Dgo, Gto, Hgo, Jal, Mex, Mich, Mor, NL, Oax, Qro, Pue, Sin, SLP, Son, Tam, Tlx, Ver, Zac

Ags, BC, BCS, Chih, Chis, CDM, Coah, Col, Dgo, Gto, Hgo, Jal, Mex, Mich, Mor, NL, Oax, Pue, Qro, SLP, Son, Tam, Tlx, Ver, Zac

BC, BCS, Coah, Gto, Jal, Mich, Son, Tam, Ver

Cam, Chih, Chis, CDM, Coah, Col, Dgo, Jal, Mex, Mich, Mor, Nay, NL, Oax, Pue, QRoo, Qro, Son, Tab, Tam, Tlx, Ver, Yuc

Cam, Chis, Coah, Dgo, NL, Oax, QRoo, SLP, Yuc

Chih

Hgo, Ver 


\section{Appendix 1. Continuation.}

Taxon

Distribution in Mexico

Scirpus microcarpus J. Presl \& C. Presl BC, Dgo

Scirpus pendulus Muhl.

Coah

Scleria $(29 / 2 / 1)$

Scleria anceps Liebm.

Chis, Ver

Scleria bellii LeBlond

Dgo, Jal

*Scleria bourgeaui Boeckeler

Scleria bracteata Cav.

Scleria ciliata Michx.

Scleria distans Poir.

Scleria eggersiana Boeckeler

Scleria flagellum-nigrorum P. J. Bergius

Scleria georgiana Core

Chih, Chis, Dgo, Jal, Nay, Ver

Cam, Chis, Gro, Oax, QRoo, Tab, Ver, Yuc

Cam, Chis, Dgo, Jal, Mex, Nay, QRoo

Chis, QRoo, Tab

Cam, Chis, QRoo, Tab, Ver, Yuc

Tab, Ver

Cam

Scleria hirtella Sw.

Scleria interrupta Rich.

Scleria latifolia Sw.

Scleria lithosperma (L.) Sw.

Scleria macrophylla J. Presl \& C. Presl

Scleria melaleuca Rchb. ex Schltdl. \& Cham.

Scleria mexicana (Liebm.) Boeckeler

Scleria microcarpa Nees ex Kunth

Scleria muehlenbergii Steudel

Scleria oligantha Michx.

Scleria phylloptera C. Wright ex Griseb.

Scleria purdiei C.B. Clarke

Chis, Mich, Nay, Oax, Tab, Ver

Cam, Chis, Jal?

Chis

Cam, Chis, Col, Gro, Mich, Oax, QRoo, SLP, Tab, Tam, Ver, Yuc

BC, BCS, Cam, Chis, Gro, Oax, Tab, Ver

Cam, Chis, Gro, Oax, SLP, Tab, Tam, Ver

Chis, Gro, Tab, Ver

Cam, Chis, QRoo, Tab, Ver

Cam, Chis, Dgo, Gro, Gto, Jal, Mex, Mich, Nay, NL, Oax, QRoo, Sin, Son, Tab, Ver

Cam, Chis, Dgo, NL, Qro, Tab, Tam, Ver

Chis, Tab

Chis

Scleria scabriuscula Schltdl. ${ }^{2}$

Chis, Jal, Nay, Ver

Scleria schiedeana Schltdl.

Scleria secans (L.) C.B. Clarke

Scleria setuloso-ciliata Boeckeler

Gro, Jal, Nay, Oax, Ver

Cam, Chis, Jal, QRoo, Tab, Ver, Yuc

Cam, Chis, Gro, QRoo, Tab, Ver, Yuc

**Scleria sp. [S. hirta Boeckeler]

Ver

Scleria tenella Kunth

Scleria vaginata Steud.

Jal, Oax, Ver

QRoo

Scleria verticillata Muhl.

NL, Tam 